\title{
FINANCIAL DEVELOPMENT AND THE GROWTH OF COOPERATIVE FIRMS
}

\author{
Francesca Gagliardi* \\ The Business School, University of Hertfordshire (UK)
}

Published in Small Business Economics: An Entrepreneurship Journal, 2009, 32 (4), pp.439-464

\begin{abstract}
The purpose of this paper is to empirically assess the relationship existing between local financial development and the growth of firms, with a special focus on cooperatives. More in detail, the interest is in investigating whether local banking development impacts differently on the growth of cooperative firms, as compared to partnerships and corporations. To pursue this aim, using Italian data, a multiplicative interaction model is specified, so as to allow the impact of local banking development to differ between cooperative and non-cooperative firms. This empirical strategy presents the distinctive advantage of offering a direct test of the hypothesis of institutional complementarity between specific features of banking institutions (i.e. their degree of development) and of firms (i.e. the legal form they assume). The main finding is that although local banking development represents a determinant of firms' growth, regardless of their legal structure, it plays a special role in boosting the growth of cooperatives: as local banking markets become more developed, cooperatives tend to grow at a rate higher than non-cooperative firms. This result provides, therefore, evidence in favor to the existence of an institutional complementarity relationship between the development of local banking institutions and cooperative firms.
\end{abstract}

JEL classification: B52; G21; L25; L30.

Keywords: Institutional Complementarities; Cooperatives ; Financial Development.

\footnotetext{
* The Business School, University of Hertfordshire, Department of Accounting, Finance and Economics, De Havilland campus, Hatfield, Hertfordshire, AL10 9AB, UK. Tel.: +44 (0)1707 285570; Fax: +44 (0)1707 285455. Email: f.gagliardi@herts.ac.uk.
} 


\section{INTRODUCTION}

The role of financial development is an issue of great interest in the analysis of the determinants of cooperative firms' growth, as it interrelates with a far more reaching research topic - the financing of cooperatives - which has received considerable attention in the economic literature. Although there exists an almost unanimous consensus in considering internal financing neither sustainable nor efficient, scholars do not reach a likewise agreement when it comes to evaluate the effectiveness of external channels in satisfying the financial needs of worker-owned firms. The mixed results existing on this issue represent the main motivation inspiring this work.

On the one hand, mainstream contributions conclude that accessing external financing entails a series of problems for cooperative firms, which result in credit rationing and higher cost of capital. These constraints not only hinder cooperatives' growth prospect, but, more severely, interpose obstacles to their creation, functioning and survival (Vanek, 1977; Putterman, 1982, 1993; Levin, 1984; Ben-Ner, 1988; Drèze, 1993; Dow, 2003). On the other hand, studies belonging to the more recent institutionalist debate argue that in the presence of supportive institutions, finance might not be a concern for cooperatives (Estrin et al, 1988; Bonin et al, 1993; Smith, 2001; Mathews, 2002 and Stiglitz, 2004). Moreover, these contributions tend to stress that since in several countries cooperative firms still represent a long lasting and significant phenomenon, this signals that - at least in certain cases - the financial matter has been governed and concretely tackled (Zevi, 2005), probably thanks to the existence of supportive financial institutions (Smith, 2001).

These new institutional conclusions, although fascinating and non trivial, appear still far from being exhaustive, thus calling for further inquiry. To this end, the contribution of the present work is to investigate the effects of local banking development on the growth of cooperative firms. According to the relevant literature, banking development is an important factor influencing firms' resources acquisition, hence their economic performance. Indeed, it has been argued that a more developed banking sector is more effective in screening and monitoring investors, thus increasing the efficiency of resource allocation (see Goldsmith, 1969 and Greenwood et al, 1990, among others). This greater ability to collect and process information may result in lower costs of bank financing (Rajan and Zingales, 1998) and greater availability of funds (Bencivenga et al, 1991; Levine, 1992). Furthermore, these positive effects may be 
particularly beneficial for firms that are more dependent upon financial intermediaries for their external financing (Benfratello et al, 2006).

The arguments just discussed make it of great interest to investigate whether the growth of cooperative firms is influenced by local banking development. To render the analysis more exhaustive, beside cooperatives also partnerships and corporations are taken into account. This choice appears to be relevant since it allows to assess whether local banking development impacts differently on the growth of diverse enterprises, hence permitting to evaluate for which business type, if any, it exerts a stronger influence. The working hypothesis is that financial development could be especially beneficial for those firms, such as cooperatives, that are particularly dependent on banks for their external financing. In order to address the research question, the analysis developed in this paper tests empirically this hypothesis by applying the institutional complementarity approach. In general terms, a relationship of institutional complementarity among the characteristics of various market governance mechanisms requires that the effectiveness, or the presence, of one governance mechanism is reinforced - either directly or indirectly - by the presence of a specific arrangement prevailing in the same or embedding domain (Aoki, 2001). Applying this concept to the issues investigated in this work, the interest is in assessing whether specific features of banking institutions (i.e. their degree of development) and of firms (i.e. the legal form they assume) are complementary in the sense that the effectiveness of firms (evaluated in terms of their growth rate) is reinforced by the presence of a particular order characterizing the financial domain (i.e. the degree of development of banking institutions).

To test this hypothesis, the empirical analysis is carried out on a sample of firms operating in the Italian provinces during the period 1995-2003. Implementing the analysis at the province level, which is the relevant local market in the Italian case, is important because there is significant evidence that credit markets are sub-national - particularly for small firms (Kwast et al, 1997; Bonaccorsi di Patti et al, 2001a), so that distance matters in the provision of funds (Petersen and Rajan, 2002; Bofondi et al, 2003). Moreover, in Italy the structure of the banking industry differs substantially across local markets and this provides sufficient cross-sectional variability within a single institutional framework (Bonaccorsi di Patti et al, 2004). 
Several features distinguish this work from the extant literature. Indeed, for the first time, the institutional complementarity approach is adopted to analyze the relationship between local financial development and firm growth, and this is particularly important if one considers that - although various theoretical treatments of the issue of institutional complementarities have been offered - the supporting empirical base is still extremely limited. Furthermore, even though previous research has investigated the impact of financial development on firm growth, this work enriches the existing literature by exploring the possibility that this effect may vary among different business types.

The remainder of the paper is organized as follows. Section 2 reviews the main literature proposed on the issue of financial development, with a special focus on the reasons that make it relevant for cooperative firms; Section 3 briefly discusses the institutional complementarity approach; Section 4 specifies the measures of firm growth and banking development used, as well as the econometric specification; Section 5 describes the data employed to implement the empirical analysis; Section 6 presents and discusses the results obtained and the sensitivity checks performed; finally, Section 7 concludes.

\section{THE ROLE OF FINANCIAL DEVELOPMENT: A REVIEW OF THE LITERATURE}

The relationship between financial development and economic performance has been analyzed by a substantial body of literature. In this line of study, several contributions investigated the economic effects of more developed banking institutions, since bank debt represents for many firms, especially small and medium sized ones, the dominant source of external financing (on this point see, for instance, Cesarini, 2003; Onida, 2004). A common conclusion reached by these studies is that financial development impacts on firms' ability to grow, hence on countries' growth prospects (see, among others, King and Levine, 1993; Levine and Zervos, 1998; Bekaert et al, 2005). ${ }^{1}$

The debate on the channels by which financial institutions affect the real economy centers on the relative importance of different, but interrelated, effects. The first one, is that better financial intermediation improves the efficiency of investments, even when it does not increase their level. In other words, financial development facilitates better screening and monitoring of investors by banks and this raises the marginal productivity of capital (Goldsmith, 1969; Greenwood et al, 1990; Fernandez et al, 1994). Evidence 
in favor to this view is offered, among others, by De Gregorio et al. (1995) and Jayaratne et al. (1996). These latter authors analyze the economic impact of the American intrastate branch banking reform. This amendment, which affected banking in 35 states since the early 1970s, relaxed restrictions on intrastate branching by both permitting bank holding companies to consolidate bank subsidiaries into branches and easing de novo branching state-wide. Jayaratne et al. (1996) find evidence that the real per capita growth rate increased significantly following intrastate branch reform. They also find that bank lending quality is the main channel through which this financial sector reform influenced economic growth.

Related to the just discussed channel, financial development can improve the economic performance at both firm and industry level by reducing the cost of raising funds from sources external to the firm, relative to the cost of internally generated cash flows (Rajan and Zingales, 1998). In broad terms, external funds are thought to be costlier because outsiders have less control over borrower's actions (Jensen and Meckling, 1976) or because they know less about what the borrower will do with the funds (Stiglitz and Weiss, 1981; Myers et al, 1984). Under such circumstances, financial development - in the form of better accounting and disclosure rules, and better corporate governance through institutions - reduces the wedge between the cost of internal and external funds and enhances growth, especially for firms that are mostly reliant on external financing (Rajan and Zingales, 1998; Benfratello et al, 2006).

Strictly related to this mechanism, is the role that financial development plays with regard to the aspect of credit availability and, thus, in fostering investment levels. According to several studies, pioneered by works as McKinnon (1973) and Shaw (1973), a more developed financial sector is better able to mobilize a larger amount of savings and translate them into investments. In other words, financial institutions insure individuals and firms against the risks associated with their liquidity needs, thus allowing them to invest in productive assets and technologies (Bencivenga et al, 1991; Levine, 1992; SaintPaul, 1992, only to quote a few).

Among the empirical analyses carried out on these issues, Demirgüç-Kunt et al. (1998) provide a micro-level test of the hypothesis advanced by King and Levine (1993) and Levine and Zervos (1998) that the extent to which financial markets and intermediaries are developed is a determinant of growth. More precisely, in order to investigate how differences in financial systems affect firms' use of external financing to finance growth, the authors estimate a financial planning model. This enables them to ob- 
tain the maximum growth rate that each firm in their thirty-country sample could attain without accessing long-term financing. Then, these predicted growth rates are compared to those realized by firms in countries with differing degree of development in their legal and financial systems. The main finding of this work is that firms in countries having active and more developed financial markets are better able to obtain external finance and grow faster.

In another interesting study, Dehejia et al. (2003) use data on U.S. state bank branching and deposit insurance regulation, which they consider an exogenous source of variation in financial development. The authors show that changes in state banking regulations have a significant impact on financial development, as proxied by the level and growth of bank loans. They also find evidence that banking development impacts on components of growth: it facilitates the shift from the agricultural to the manufacturing sector, has a positive effect on human capital accumulation and also on wealth acquisition.

Using a firm-level survey database covering 44 countries, Beck et al. (2003) analyze the relationship between firm size and the development of banking institutions and legal protection of investors. With regard to the former aspect, which is more prominent for the issues under discussion, the authors find that there exists a positive relationship between the level of development of a country's banking system and firm size. Furthermore, this impact is stronger for firms that depend more heavily on external finance. Continuing to employ a firm-level survey database, this time covering 54 countries, Beck et al. (2005) find that financial and institutional development weakens the constraining effects of financial, legal and corruption obstacles to firm growth. They also find that small firms, which are those more constrained by corruption, benefit the most from financial development.

Working on Italian data, Guiso et al. (2004) investigate the effect of financial development within regions. To measure financial development, these authors build a local indicator of how much more likely an individual is to obtain credit in a region, rather than in another one. Therefore, this index is a measure of how easy it is for an individual to borrow at the local level and is based on the notion that developed financial markets grant individuals and firms easier access to external funds. The empirical analysis finds strong effects of local financial development: in more financially developed regions individuals are more likely to become entrepreneurs at a younger age; more firms are created and firms grow more; finally, per capita income is higher. 
Recently, Benfratello et al. (2006) have analyzed the impact of local banking development on the innovative activity of Italian firms during the period 1992-2000. They find that local banking development, as measured by branch density, has a positive effect on the probability that a firm introduces a process or product innovation. In particular, for process innovation the effect is larger for small firms operating in more high-tech sectors and in sectors characterized by a greater need of external finance.

To sum up, the literature surveyed in this section, summarized in schematic form in table 1 , strongly supports - both at the micro and macro levels - the existence of a close link between financial development and economic performance, thus providing scope to inquiry into the effects of local financial development for the growth of different typologies of enterprises.

\section{[Insert table 1]}

\subsection{Why should financial development matter for the growth of cooperatives?}

The role of financial development assumes a particular relevance in the analysis of the determinants of cooperative firms' growth, if one considers the controversial debate existing in the literature on the financing of cooperatives, along with the characteristics of cooperatives' financial structure and firmspecific resources. Indeed, although there exists an almost unanimous consensus in considering internal financing neither sustainable nor efficient, due to the bias toward short-term investment and/or underinvestment created by the so-called horizon problem (Pejovich, 1969; Furubotn and Pejovich, 1970, and Vanek, 1970, 1977), ${ }^{2}$ scholars do not reach a likewise agreement when it comes to evaluate the effectiveness of external channels in providing worker-owned firms the required financial resources.

The main source of external financing for cooperatives has typically been bank credit. However, it has been argued that compared to other typologies of enterprises, the bank-firm link is more complex for cooperatives, as these latter face more difficulties in raising the required external capital, due to the problem of guarantees offered to third parties financing the firm (Jossa and Cuomo, 1997). On the one hand, in fact, workers' typical limited wealth bounds the personal collateral available for obtaining loans (Ben-Ner, 1988); moreover, on the other hand, the so-called cooperatives' vaguely defined property rights (Cook, 1995) create a commitment problem of members (Schlicht et al, 1977), which makes agency problems in credit markets more severe for these firms than for other business types, so 
that cooperatives are likely to face higher costs of capital and credit rationing (Drèze, 1993; Putterman, 1993; Dow, 2003). ${ }^{3}$

The difficulties that cooperators might face in obtaining or providing financial capital for their firm have been used as an argument against the viability of cooperatives (Blair et al, 2000). Indeed, a major conclusion reached by the mainstream literature on cooperative firms so far discussed is that employees' limited wealth and consequent risk aversion and liquidity constraints, combined with cooperatives' atypical property rights structure, pose severe limits to the creation, functioning and survival of this organizational mode of firm (see, among others, Vitaliano, 1983; Drèze, 1993 and Putterman, 1993).

Despite the widespread theoretical consensus that such a conception of the cooperative firm enjoyed for a long time, several objections to it have been lately put forward by studies mainly belonging to the institutionalist literature. A common feature of the contributions proposed within this strand of analysis is to have stressed the role played by institutions in favoring cooperatives' flourishing and success. These contributions, in fact, do not find particular problems with regard to the effectiveness of external sources of financing, once a set of supportive financial institutions is present (Estrin et al, 1988; Bonin et al, 1993; Smith, 2001). It has, indeed, been argued that since the problems arising in the presence of credit market failures ${ }^{4}$ are particularly acute when financial institutions have scarce experience in lending to cooperatives, the existence of supportive financial institutions represents a crucial factor, especially if this tends to favor the acquisition of information about cooperatives' credit riskiness (Bonin et al, 1993; Smith, 2001).

Moreover, these studies also tend to stress that institutions can reduce agency costs between ownership and management, thus rendering less acute the incentive problem of free-riding by team members, and encouraging mutual monitoring (Staber, 1989; Bartlett et al, 1992; Bonin et al, 1993; BayoMoriones et al, 2002). As a result, this may allow cooperatives to achieve even better productivity and performance than conventional firms.

It is important to point out that this literature tends to emphasize at least two additional important aspects. The first one is that conventional economic indicators of performance and efficiency provide an incomplete basis for comparing cooperative and capitalist firms, since these enterprises operate under, at least partially, different sets of objectives (Bartlett et al, 1992). Indeed, it can be argued that the major 
discriminant between cooperative and capitalist firms lies in the role ascribed to capital: in the former, capital is an instrument necessary to realize the ultimate aim of those that decide to join in a cooperative, would this be the satisfaction of a need, the procurement of a job, and so on; by contrast, in the latter capital is both instrument and ultimate aim. Put it in other words, beside economic purposes, cooperatives also pursue social goals; therefore, the role of relational goods - often able to counterbalance freeriding and promote economic performance - cannot be disregarded (Zamagni, 2005). On this regard, the mutual aid concept, which is the pivotal principle of the cooperative logic, implies that the most important assets of the firm are the members themselves, who are mutually reliant on one another to produce the sociability that makes membership in the firm worthwhile (Alchian et al, 1988). So that, a distinctive set of firm-specific resources is what could be called "relational capital", with this meaning the set of intangible assets in the form of social relations and social values - embedded in the local community, and reproduced through the interactions taking place within it - which play a crucial role in the economic governance of cooperatives, in the sense that they facilitate the processes that support economic activity and economic transactions by protecting property rights, enforcing contracts, and taking collective action to provide appropriate physical and organizational infrastructure (Dixit, 2007).

The second aspect stressed, perhaps even more relevant, is that the evidence contradicts mainstream theoretical predictions, as cooperative firms still represent (at least in some countries) a long lasting and significant phenomenon (Stiglitz, 2004; Zamagni, 2005). ${ }^{5}$ Therefore, this seems to suggest that the financial issue has been governed and concretely tackled in some way, and where this has not occurred, it turned out to be a severe impediment to the development of cooperatives (Zevi, 2005). ${ }^{6}$

With regard to the Italian case, in order to stimulate the capitalization of cooperative firms through the conferment of funds by third parties, the 59/1992 Law introduced the figure of financial backer member (i.e. socio sovventore), a category of partners having the role of financiers, but not engaging in the mutualistic exchange. By attributing to these external members up to one third of votes in the company meetings, this reform, and more generally those introduced in the last fifteen years in most European countries, altered the traditional cooperative principle "one head, one vote", hence - at least potentially - the governance of these firms. ${ }^{7}$ However, lacking so far any clear-cut answer as to the actual impact of the legislative changes introduced in the Nineties, it should not be neglected to consider 
that the very reason motivating them was the need to attract the resources, scarce for cooperatives, required to foster growth. So that, the figure of financial backer member, along with the participatory rights it assigns, can be regarded functional to fulfil the instrumental role of capital in cooperative firms. And indeed, in order to reconcile the non-profit nature of cooperatives with the profitability strategy of financial backer members, so as to increase the amount of financial resources that could have been attracted, the 59/1992 Law established that these financiers, beside the vote right previously mentioned, could also receive a remuneration higher than the one assigned to cooperator members, even though this extra-dividend could not be greater than $2 \%$. Whether or not this reconcilement of interests has been achieved is still debated among observers, who also question the effectiveness of the reform itself. On this regard, it has been argued that the 1992 Law did not respond adequately to the needs that motivated it, since the amount of financial resources it has been able to mobilize did not match cooperatives' requirements, possibly because the new financial instruments have never been sold in official financial markets (La Loggia Albanese, 2003; Salani, 2005; Zevi, 2005).

A further relevant issue characterizing the Italian case is that until 2003, although most of the corporate law regulating corporations applied also to cooperatives, an important element of differentiation in the discipline of these two business types was relative to the financial instruments they could access, since an institutional constraint bounded the sources of external financing available to cooperatives. Afterwards, with the 2003 corporate law reform, the lawmaker acknowledged cooperatives the possibility of using a wider range of financial instruments. However, given the relatively short time that has elapsed since then, it seems reasonable to expect that the effects of this reform (both in terms of financing and corporate governance), will be displayed only after a longer time will have passed, so that bank credit can still be regarded the main source of external financing for cooperatives.

Considering the arguments so far discussed it can be argued that - although banks represent the primary source of external financing also for partnerships, and a nonetheless important channel of resources acquisition for corporations - financial development can be particularly relevant in the case of cooperatives, as it might mitigate some of the previously discussed difficulties experienced by these firms, hence contributing to cater their financing requirement. 


\section{THE INSTITUTIONAL COMPLEMENTARITY APPROACH}

The concept of institutional complementarity appeared recently in the economic literature dealing with the importance of institutions in the economy and varieties of capitalism. Intuitively the term "institutional complementarity” refers to situations in which an interdependence among institutions occurs. The relevance of this relationship is due to the fact that since each institution defines a set of constraints, incentives and possibilities that determine agents' strategies, the influence of one institution is reinforced when a complementary institution is present (Amable, 2000). However, complementarity has a variable impact depending on the general context in which such a relationship is embedded (Boyer, 2005).

Several elaborations of the institutional complementarity hypothesis and its implications have been proposed in the literature. Amongst these, Aoki (2001) argues that the relationships among various market governance mechanisms in one economy at one point in time may be complementary in the sense that the effectiveness (or the presence) of one governance mechanism can be reinforced, either directly or indirectly, by the presence of a particular mechanism in the same or embedding domain. For instance, market-supporting moral codes, inducing contracts' self-enforceability, can be complementary to a just system of the rule of law (Aoki, 2001, p. 87). ${ }^{8}$ Using a simple model, the author shows that in the presence of institutional complementarities across domains, the prevailing institutional arrangements are not necessarily Pareto improving, as they may be Pareto sub-optimal, as well as Pareto non-rankable. This is so because, due to their bounded rationality in perception and choice, agents cannot strategically coordinate their choices across different domains, even if they participate in them simultaneously.

Another interesting study is the work of Boyer (2005), who points out that the institutional complementarity hypothesis is able to elucidate many stylized facts about the evolution and diversity of institutional architectures. In particular, institutional complementarities explain that most benchmarking experiments do not deliver the expected results since the web of past interdependency between institutions hinders the adoption of new ones. In Boyer's (2005) conceptualization, two institutions $E$ and $E$ ' are complementary if the performance $R$ of the conjunction of $E$ and $E^{\prime}$ is superior to the performance of each institution considered separately:

$R\left(E, E^{\prime}\right)>R(E)$ and $R\left(E, E^{\prime}\right)>R\left(E^{\prime}\right)$ 
Therefore, in this analysis complementarity requires that the conjunction of two institutions is Pareto improving with respect to the existence of only one of the two entities.

With regard to the sphere of applicability of the institutional complementarity theory, Amable et al. (2005) argue that this approach allows a theoretically grounded interpretation of the persistent diversity of industrial relations models. In a stylized model of an economy with two strategic actors, a labor union and firm management, ${ }^{9}$ a taxonomy of four different types of industrial relations is identified according to union's relative strength and the strategy followed by each side, under the influence of external creditors. This taxonomy is then interpreted in terms of the institutional complementarity approach of which, according to these authors, two definitions can be conceived. In a first meaning, referring to a measure of performance, and thus close to Boyer's (2005) definition, strong and influential financial markets are complementary to a weak union, whilst less influential financial markets are complementary to cooperative relations between union and management. In fact, both configurations lead to a higher survival probability for the firm. With respect to the second definition - close to Aoki's (2001) conceptualization this refers to the concept of dynamic stability and identifies, once again, a complementary relation between weak financial markets and cooperative strategies, since strong financial markets have a destabilizing effect.

Interestingly, Nicita et al. (2004) apply the concept of institutional complementarity to the relationship intervening between corporate governance and corporate finance. The authors explain the emergence and persistence of diversity in corporate models in terms of the emergence of institutional complementarities between firm's technological and financial structures. In a model analyzing the trade-off between equity and debt financing in corporate governance, the authors show that, whilst Williamson's (1988) transaction costs approach considers the choices on the financial domain as an endogenous adaptation to a given technological domain, an opposite direction of causality may also hold: technological choices may be an endogenous adaptation to given financial choices. Moreover, when both the directions of causality hold, some self-enforcing equilibria across the two domains can prevail, so that this provides some insights against the tendency towards convergence proposed by corporate governance models.

Basili et al. (2004) develop a principal-agent model investigating the conditions which make the use of trust beneficial for the parties involved in a transaction, and show that since trust generates costs, the 
willingness to reciprocate does not suffice by itself to resort to trust. By contrast, the presence of complementary institutions induces cooperation between individuals, thus representing a crucial variable to foster the choice of trust (rather than contracts) as a mechanism for governing transactions.

With regard to the empirical research on the issue of institutional complementarities, only a few studies have been so far proposed in the literature. Among these, Ernst (2003) estimates a multiplicative interaction model analyzing the interrelations that may exist between specific institutional arrangements prevailing on financial and labor markets, and that may produce effects on macroeconomic outcomes. The analysis, performed using data on output growth in 27 manufacturing industries in 19 OECD countries over the period 1979-1995, provides support to the hypothesis of institutional complementarities between specific configurations of financial and industrial relations: they explain an important part of within industry variation among countries. More in detail, concentrated ownership structures and unionized industrial relations are complementary in promoting growth in industries with high skill levels and also in bank financed industries, whereas ownership dispersion and labor market flexibility foster growth in equity financed industries.

In the Varieties of Capitalism literature, Hall et al. (2004) test the hypothesis that institutional complementarities occur across sub-spheres of the macroeconomy. By distinguishing the structure of labor relations and corporate governance prevailing in coordinated market economies and liberal market economies, the authors argue that if the institutionalized practices typical of each of these two typologies are complementary, then they should exert an impact on economic growth. In order to carry out a direct test of the institutional complementarity hypothesis, Hall et al. (2004) employ multiplicative interaction effects between variables proxying for institutions operating in the spheres of corporate governance and labor relations. Since these interaction terms are found to significantly exert a positive impact on growth, the authors conclude that this is empirical evidence in favor to the existence of complementarities between the two spheres considered.

The conclusions reached on both theoretical and empirical grounds by the analyses so far discussed allow to argue that taking into account the issue of institutional complementarity makes it prominent to study the effects of interacting institutions, rather than simply recognize that 'institutions matter', as any 
policy recommendation aimed at introducing a structural reform should consider the coherence and logic of the whole institutional structure (Amable, 2000).

\section{EMPIRICAL QUESTION AND METHODOLOGY}

This work intends to empirically assess the relationship existing between local banking development and the growth of Italian firms, with a special focus on cooperatives. More precisely, the interest is in investigating whether local banking development impacts differently on the growth of cooperative firms, as compared to partnerships and corporations (henceforth, non-cooperative firms). ${ }^{10}$ The reasoning set out in sub-section 2.1, should have clarified that the cooperative legal form has still strong implications in terms of financial structure of these firms, structure characterized - more than for any other typology by the relevance of bank financing. So that, although it is not disputed that, in general, the benefits of a more developed banking sector are contingent upon firm financial structure, the working hypothesis is that these benefits could be especially marked for cooperatives, given their institutional structure. ${ }^{11}$ In order to address the research question, the empirical analysis tests this hypothesis by applying the institutional complementarity approach à la Aoki (2001): the interest is in assessing whether specific features of banking institutions (i.e. their degree of development) and of firms (i.e. the legal form they assume) are complementary in the sense that the effectiveness of cooperatives (evaluated in terms of their growth rate) is reinforced by the presence of more developed local financial intermediaries.

To carry out this test, following the extant empirical literature on institutional complementarity, a multiplicative interaction model is specified, so that the impact of local banking development on firm growth is allowed to differ between cooperatives, on one side, and non-cooperative firms, on the other side. ${ }^{12}$ In other words, in this model the partial effect of local banking development (BRANCH) on firm growth (GROWTH) is made conditional on firm's legal structure (COOP). More precisely, the marginal effect of BRANCH is given by

$$
\frac{\partial G R O W T H}{\partial B R A N C H}=\hat{\beta}_{B R A N C H}+\hat{\beta}_{I N T E} * C O O P
$$


where $\hat{\beta}_{B R A N C H}$ is the marginal effect of local banking development on the growth of non-cooperative firms, whilst $\hat{\beta}_{I N T E} * C O O P$ is the estimated coefficient on the interaction term multiplied by the conditioning dichotomous variable COOP, which is equal to 1 when the condition "firm is a cooperative" is met. From equation (2) it follows that the marginal effect of local banking development on the growth of cooperative firms is $\hat{\beta}_{\text {BRANCH }}+\hat{\beta}_{\text {INTE }}$. In order to test the significance of (2), it is necessary to compute the standard error of this quantity, which is given by:

$$
\hat{\sigma}=\left[\operatorname{var}\left(\hat{\beta}_{\text {BRANCH }}\right)+C O O P^{2} \operatorname{var}\left(\hat{\beta}_{I N T E}\right)+2 C O O P \operatorname{cov}\left(\hat{\beta}_{B R A N C H} \hat{\beta}_{I N T E}\right)\right]^{1 / 2} .
$$

The analysis carried out in the paper refers to manufacturing firms. However, since cooperatives operate in a number of different sectors, from food industry to a broad range of services, as well as social activities, this is a limitation. Future research is, therefore, called to fill this gap.

The following sub-sections present the measures of firm growth and local banking development, and discuss the other variables included in the empirical specification, as well as the econometric strategy adopted.

\subsection{Measuring firm growth}

To test the previously discussed research question, it is first necessary to define the measure of firm growth employed in the empirical analysis. Real sales are the chosen indicator of growth; therefore, the dependent variable is the annual growth rate of firm's real sales.

Although several other measures have been used in the literature on firm growth, focusing on sales appears to be appropriate for a series of reasons. Firstly, beside employment, this is the most widely used indicator in empirical growth research (Delmar, 1997) and there seems to be an emerging consensus that if only one indicator is to be chosen as a measure of firm growth, this should be sales (Hoy et al, 1992; Sutton, 1997; Ardishvili et al, 1998; Delmar et al, 2003). Secondly, data on sales are relatively easily accessible and are insensitive to capital intensity and degree of integration (Delmar et al, 2003). Thirdly, sales are a suitable indicator across different conceptualizations of the firm (Davidsson et al, 2000). Finally, demand and, therefore, sales are a precursor of growth in other indicators (Flamholtz, 1986; Delmar, 1997). Despite the aforementioned advantages, drawbacks of sales as a growth indicator 
are that this measure is sensitive to currency exchange rates and inflation. This latter problem, however, is not a concern in this work, since firms' growth rates are computed on real sales. ${ }^{13}$

\subsection{Measuring local banking development}

Following Benfratello et al. (2006), local banking development is measured for province $p$ and year $t$ as number of bank branches normalized by population:

$$
\text { BRANCH }_{p t}=\frac{\text { bankbranches }_{p t}}{\text { population }_{p t}} \text {, where } p=1, \ldots, 103 ; t=1995, \ldots, 2003 .
$$

This variable describes the structure of the banking system in the provinces and, in particular, captures the geographic expansion of banks within the market (Bonaccorsi di Patti et al, 2001b). One main advantage of using BRANCH to measure local financial development is that this variable is available on a homogeneous basis for long periods of time (Benfratello et al, 2006).

\subsection{The econometric specification}

As already mentioned, in the empirical model the dependent variable is the annual growth rate of firm's real sales (GROWTH), while BRANCH is the main explanatory variable. The vector of other regressors includes the following variables accounting for firm specific, local market and sectoral characteristics: firm size (EMPLOY), which is measured as number of employees and, according to the relevant literature in the field, could exert either a relevant or insignificant impact on firm growth; ${ }^{14}$ firm age (AGE), expected to be negatively related to GROWTH; $;^{15}$ firm cash flow (CASHFLOW), which is measured as the sum of declared income, depreciation and quiescence fund scaled by total assets, and is a proxy for internally generated finance (Carpenter et al, 2002), hence for firm liquidity constraints (Fagiolo et al, 2006); ${ }^{16}$ the ratio of bank loans (i.e. short and long-term bank debts) on firm's total assets (BANKDEBT), indicating the proportion of bank debt a firm employs to finance its assets; a dummy variable distinguishing between different firms' legal structures (COOP), taking on the value of 1 for cooperatives and 0 for non-cooperative firms; an interaction term (INTE) between BRANCH and COOP, accounting for the possibility that the impact of local banking development on firm growth varies with 
firm legal structure; a dichotomous variable taking on the value of 1 if the firm belongs to a group and zero otherwise (GRU); (the log of) provincial population (POP) as a measure for province size; provincial real per capita income (RPI), proxying for local wealth; a dichotomous variable taking on the value of 1 for Centre Northern provinces and 0 for Southern ones (CEN-NORTH); three dummy variables distinguishing between firms operating in the supplier dominated, scale intensive, or specialized suppliers sectors (PAV), to control for sectoral heterogeneity within the manufacturing industry (the control group is the science based sector); ${ }^{17}$ finally, time dummies are included to control for year fixed effects. ${ }^{18}$ In order to mitigate any potential simultaneity bias all variables have been lagged one year. ${ }^{19}$

The econometric specification is estimated by applying the technique of panel data. It is worth mentioning that rather than estimating separate equations for cooperative and non-cooperative firms, the empirical analysis is implemented on the whole sample. Then, by introducing the dummy variable COOP and the interaction term INTE, it is possible to distinguish between firms' legal structures and analyze if local banking development impacts differently on the growth of diverse typologies of enterprises. Such an empirical strategy presents two main advantages: firstly, the number of cooperatives present in the original dataset is rather limited ${ }^{20}$; secondly, using the multiplicative interaction term INTE allows to test directly for the presence of complementary relationships between specific features of the banking system and of business types.

For a more detailed description of the variables presented in this section and for their main summary statistics see tables 2 and 3, respectively.

[Insert tables 2 and 3]

\section{DATA}

The dataset used to implement the econometric analysis covers the nine-year period 1995-2003 and has been derived combining information obtained from three main sources. Firstly, data on firms come from the last three waves of the survey "Indagine sulle imprese manifatturiere" conducted with triennial cadence by Capitalia's observatory on small and medium sized enterprises. The sample of Italian manufacturing firms used in the surveys is stratified and randomly selected for firms with 11 to 500 em- 
ployees, while it is by census for firms with more than 500 employees. Data collected through the surveys are both qualitative and quantitative. Qualitative information is obtained by dispensing a questionnaire to sample firms and is referred to the end of the three-year period of each survey wave, whilst quantitative data are obtained from examining firms’ yearly balance sheets.

Information collected through the questionnaire, which is made up of six sections, covers a number of aspects. The first section gathers information on establishment year, legal form, prevailing sector of activity, ownership and control, and participation in consortia activities. The second section collects data on employment, whilst the third one examines investment and $R \& D$ activities, and their financing. The fourth section is concerned with the internationalization process, and covers aspects such as the export activity, its geographical distribution, foreign direct investments etc. The fifth part of the questionnaire analyzes firm's market and gives information on distributive channels and characteristics of main competitors. Finally, the sixth section deals with the issue of firm financing, and contains questions regarding banking relationships, the access to the latest financial instruments, the use of financial incentives and several other pieces of information.

The dataset for the period 1995-2003 is made up of 6,452 firms. Since not all firms are present in each survey wave, the panel is unbalanced and made up of 28,185 observations. A careful examination of the original dataset showed that in some cases the year of firm establishment was taking on two clashing values. To correct these inconsistencies, and homogenize the sample, the mean value of the two clashing years has been imputed when the time span was less than a decade, whilst excluding from the sample observations for which the time span elapsing between the two clashing years was longer than ten years. After operating these adjustments, the sample consists of 25,491 observations.

With respect to the sub-sample of cooperatives, this includes 190 firms, for a total of 831 observations. Of these, 26.3\% (amounting to 219 observations) operate in Southern regions, whilst 73.7\% (i.e. 612 observations) are run in Centre Northern ones. Moreover, regarding the Pavitt sectoral distribution of sampled cooperatives, 160 firms (for a total of 696 observations) belong to the supplier dominated sector, 21 cooperatives (amounting to 96 observations) operate in the scale intensive sector, 9 firms (amounting to 39 observations) are in the specialized suppliers sector, whilst none of the cooperatives included in the sample belongs to the science based sector. As far as the number of employees is con- 
cerned, 26.3\% cooperatives (amounting to 216 observations) employ between 11 and 20 workers, 44.2\% (for a total of 405 observations) have between 21 and 50 employees, 22.1\% firms (equal to 153 observations) employ between 51 and 100 workers, 3.2\% (amounting to 27 observations) have between 101 and 250 employees, finally, 4.2\% cooperatives (amounting to 30 observations) employ between 251 and 500 workers. ${ }^{21}$

After correcting for the presence of outliers, and excluding sole traders and firms classified in the category "other legal structures", the number of observations for each variable employed in the empirical investigation is reported in table $3 .^{22}$

A second source of data comes from the Bank of Italy and regards the provincial distribution of branches for each Italian bank over the period considered in the analysis. Finally, figures on provincial population and real value added are drawn from the Italian National Statistical Institute (ISTAT).

\section{RESULTS}

Estimation results are presented in tables 4-8. Since the Breusch-Pagan Lagrange Multiplier test always favors the linear regression model against the random effects one, figures reported in these tables are obtained from running pooled regressions. All estimations have been carried out by using robust standard errors. Looking at table 4, MOD1 reports the results for the general model of firm growth. Since some of the control variables turn out to be not statistically significant, the general-to-simple procedure of reiterated elimination is applied to the specification of MOD1 and several nested models are estimated. Firstly, being CEN-NORTH the less statistically significant variable, this is excluded from the model and estimations are re-run on MOD2. Then, since results obtained for MOD2 reveal that POP is not statistically significant, this is not included in MOD3, which is the final model. ${ }^{23}$ Estimation results for MOD3 are reported in table 4.

\section{[Insert table 4]}

To begin with the comment on the significant control variables, figures for MOD3 in the above table suggest an inverse relationship between firm size and firm growth; this result, in line with most studies 
(such as Mata, 1994; Weiss, 1998; Audretsch et al, 1999; Becchetti et al, 2002), rejects Gibrat's law of proportionate effects, according to which firm growth should be independent of size. A negative impact on GROWTH is also found for AGE and this suggests - in line with the a priori expectations and the findings of studies as Glancey (1998) and Davidsson et al. (2002) - that younger firms grow faster. Moreover, the results show that CASHFLOW is inversely related with firm growth, ${ }^{24}$ and that firms employing a larger amount of bank debt (BANKDEBT) and those belonging to a group have higher growth rates (GRU). It is, then, found that firms located in less wealthy provinces grow more (RPI) and this result could be interpreted as evidence of a convergence effect. Finally, firms operating in supplier dominated (PAV1), scale intensive (PAV2), and specialized suppliers (PAV3) sectors grow less than those working in the science based sector (PAV4).

Passing to the main variables of the investigation, the results suggest that, other things being equal, cooperatives tend to grow less than non-cooperative firms (COOP). This result would seem to support those studies claiming that the institutional characteristics of cooperative firms pose constraints to their performance (see, for instance, Vitaliano, 1983; Putterman, 1993). Moreover, the empirical evidence shows that local banking development is an important determinant of firm growth: the sign on BRANCH suggests that local banking development has a positive impact on the growth of noncooperative firms. The beneficial effect of BRANCH on GROWTH is even stronger for cooperative firms, since the positive sign on the interaction term INTE indicates that as local banking markets become more developed, cooperatives tend to grow at a rate higher than non-cooperative firms. This result seems to provide evidence in favor to the existence of a relationship of institutional complementarity in the sense à la Aoki (2001): the effectiveness of cooperative firms, measured in terms of their growth rate, is reinforced by the presence of more developed local banking institutions. In order to evaluate this finding, it should be recalled that, as pointed out in sub-section 2.1, cooperatives' financial structure is such that they still rely more than other firms on bank financing, since reforms as the 59/1992 did not respond adequately to the need of stimulating the capitalization of these firms, and the corporate law in force before 2003 bounded the sources of external financing they could access. At the same time, however, their atypical property rights structure implies that cooperatives face more difficulties in raising the required external capital (Putterman, 1993; Dow, 2003), due to the problem of guarantees offered to third parties 
financing the firm (Ben-Ner, 1988; Cook 1995; Jossa and Cuomo, 1997; Schlicht, 1997). So that, considering these arguments, the evidence obtained could be interpreted as suggesting that banking development allows financial intermediaries to better collect and process the information embedded in the local market, therefore reducing the scope for moral hazard and adverse selection (Goldsmith, 1969; Greenwood et al, 1990). In turn, this tends to favor the reproduction of some cooperatives' firmspecific resources, as social relations and social values, which are embedded in the local community and are important for the economic governance of these firms (see sub-section 2.1). So that, it could be through these channels that banking development particularly enhances the growth of cooperatives. ${ }^{25}$ And this seems to be evidence in favor to Rajan and Zingales (1998) and Benfratello et al. (2006), who show that financial development especially benefits firms mostly dependent on banks for their external financing.

Finally, it is worth noting that the variables BRANCH and INTE are statistically significant when considered individually and also when tested jointly.

\subsection{Robustness checks}

A potential objection to the analysis presented is that BRANCH may be endogenous, if local banking markets tend to be more developed where firms' growth rates are higher for exogenous reasons. A similar reasoning could apply also to BANKDEBT and CASHFLOW. Therefore, to address this potential issue MOD3 is re-estimated by testing for endogeneity. The instruments used to implement this check are: the provincial area in square kilometers (AREA); the number of municipalities present in the province (MUNI); the geographical dummy CEN-NORTH; one lag of BANKDEBT, and CASHFLOW, also this lagged once. Results from this estimation are reported in table 5.

\section{[Insert table 5]}

Figures for MOD3 in the above table show that the Wu-Hausman and Durbin-Wu-Hausman tests find no evidence of endogeneity; moreover, the Hansen-Sargan test reveals that the instruments employed are valid. Therefore, the results previously discussed for MOD3 are fully confirmed. 
To check the robustness of the empirical specification, some new variables are then introduced. In order to account for the impact of investments on firm growth, the model is estimated by including the variable INV, measured as investments in installation, machinery, and equipment on total assets. ${ }^{26}$ Results from this check are presented in column MOD4 of table 5. Figures obtained for INV show that, as expected, firms investing more have a higher growth rate. Moreover, the previous findings continue to be valid, as no change is registered neither for the core variables of this study (BRANCH, COOP, INTE), nor for the control ones.

The next step of the robustness analysis is to include INV among the endogenous regressors in the specification testing for endogeneity, since also INV may be endogenous, at least potentially. To carry out the two stage least squares regression, beside the instruments previously used, INV lagged once is included as well. Results obtained from this check on MOD4 do not show evidence of endogeneity (see table 5), thus confirming the conclusions discussed in the previous section.

To take the robustness analysis a step further, the original specification (MOD1) is estimated by changing the dependent variable: firm growth is now measured as the annual growth rate of employees (GROWTH2). ${ }^{27}$ Furthermore, EMPLOY is replaced with SIZE1 (measured as the log of real sales lagged once), and INV is included as well. Results from this sensitivity check are reported in column MOD5 of table 6.

\section{[Insert table 6]}

Figures for MOD5 in the above table show that, although some control variables are no longer significant, the main conclusions of this study are confirmed: local banking development is beneficial for the growth of non-cooperative firms (BRANCH); this positive impact is even more marked for cooperatives (INTE), thus suggesting that financial development contributes to mitigate some of the initial disadvantages that cooperatives - compared to other enterprises - experience (COOP). These same conclusions are reached also when firm size is first measured by (the log of) total assets lagged once - SIZE2 (MOD6 in table 6) and then by EMPLOY (MOD7 in table 6).

As a further check, since firm growth in one period is likely to be affected by unobserved area specific factors, which may be at work also in other periods, the robustness analysis clusters observations at 
the province level. Indeed, clustering makes allowance of within zone correlation of the error terms over time, so that it is necessary to correct standard errors and tests statistics for within cluster correlation. The regressions re-run by clustering on provinces are relative to MOD3 (table 4), MOD4 (table 5), and the models having GROWTH2 as dependent variable (table 6). Figures from these estimations are presented in table 7.

\section{[Insert table 7]}

Some other checks performed regard the inclusion in all regressions of firm's return on equity (ROE), previously not included for the expected collinearity with CASHFLOW. In all cases, results (not reported, but available from the author upon request) remain basically unchanged, thus supporting the major conclusions of this research.

\section{[Insert table 8]}

Table 8 reports figures on the significance of the quantity of interest (the impact of BRANCH on GROWTH when COOP=1), computed by applying expression (3), and on the relevant marginal effects. ${ }^{28}$

\section{CONCLUSIONS}

The aim of this paper has been to empirically investigate whether local financial development influences the growth of Italian firms. More precisely, to assess if the degree of development of local credit markets impacts differently on the growth of diverse business types, the empirical analysis allowed the effect of local banking development on firm growth to differ between cooperative and non-cooperative firms.

The econometric investigation, implemented on a sample of Italian firms for the period 1995-2003, leads to two main conclusions. The first one is that, compared to non-cooperative firms, cooperatives tend to grow less. In fact, the empirical evidence seems to suggest that, even after controlling for firm specific and local market characteristics, cooperatives exhibit a lower growth rate. Thus, this result would seem to support those studies claiming that the institutional characteristics of cooperative firms pose constraints to their performance (see, for instance, Vitaliano, 1983; Putterman, 1993). 
A second result, which is also the major conclusion of this research, is that local banking development is a determinant of firm growth, since firms operating in more developed credit markets are found to have higher growth rates. Therefore, this seems to indicate that the characteristics of the context in which firms operate influence their performance (Boyer, 2005). Even more importantly, the results suggest that the beneficial effect of local financial development is stronger for cooperative firms: as local banking markets become more developed, cooperatives tend to grow at a rate higher than noncooperative firms. This seems to be empirical evidence in favor to the existence of a relationship of institutional complementarity between local banking institutions and cooperative firms, as the effectiveness of cooperatives, evaluated in terms of their growth rate, appears to be reinforced by the presence of more developed local financial intermediaries.

This conclusion, in line with studies claiming the importance of supportive financial institutions in favoring cooperatives’ flourishing and success (Estrin et al, 1988; Bonin et al, 1993; Smith, 2001; Mathews, 2002; Stiglitz, 2004, amongst others), could be interpreted as suggesting that banking development allows financial intermediaries to better collect and process the information embedded in the local market, therefore reducing the scope for moral hazard and adverse selection (Goldsmith, 1969; Greenwood et al, 1990). In turn, this tends to favor the reproduction of firm-specific resources, as social relations and social values, which are embedded in the local community and are important for the economic governance of cooperatives. So that, it could be through these channels that banking development particularly enhances the growth of cooperatives. And this seems to be evidence in favor to Rajan and Zingales (1998) and Benfratello et al. (2006), who show that financial development especially benefits firms mostly dependent on banks for their external financing.

Regarding the interpretation of these results at a policy level, it could be argued that initiatives aimed at promoting a relatively more deregulated banking system would represent an important step towards the creation of an institutional context that strengthens firms, especially cooperatives, hence promoting economic activity. 


\section{ACKNOWLEDGMENTS}

In writing this version I benefited from the comments of Geoffrey M. Hodgson, Avinash K. Dixit, Douglass C. North, Giovanni Dosi, Jesse M. Fried, Francesco Trivieri, the participants to the European School on New Institutional Economics held in Cargese on 21-25 May 2007, and two anonymous referees. I thank Attilio Pasetto from Capitalia for his kind elucidations. I am also grateful to Mariarosaria Agostino, Elena Granaglia, Rosanna Nisticò and the participants to the Centre for Research in Institutional Economics Workshop held at the University of Hertfordshire on 23-24 January 2007, for their valuable comments and suggestions on earlier versions of this paper. Of course, all remaining errors and omissions are mine. 


\section{NOTES}

${ }^{1}$ It is worth mentioning that in this literature a large number of contributions have focused on cross-country analysis (see Levine, 1997 for a survey of the main studies), while fewer works have investigated within-country differences.

${ }^{2}$ The horizon problem concerns the impossibility for partners to recoup the self-financed capital invested in the firm when their expected tenure in the firm is shorter than the time it takes for the stream of discounted net returns from the project to equal the initial cost of the investment.

${ }^{3}$ According to Pejovich (1992), two critical variables determining the availability of bank loans are cooperators' time horizon and the length of bank credit. Members of a producer-owned firm would prefer to obtain bank loans when the length of the loan is longer than their time horizon with the firm. By contrast, banks would prefer to extend loans in the opposite case, that is when the length of the loan is shorter than the time horizon of members. Consequently, cooperatives might not be able to obtain bank credit due to the mismatch between members' time horizon and the length of the bank loan.

${ }^{4}$ An applicable formal model of credit market failures has been proposed by Banerjee and Newman (1993).

${ }^{5}$ A number of studies have, in fact, stressed that the empirical base underlying the traditional theory of the cooperative firm is very thin (see, amongst others, Stephen, 1984; Estrin and Jones, 1992; Ménard, 2004).

${ }^{6}$ However, Zamagni (2005) argues that the evidence alone does not suffice to invalidate an analytically proved theory. Therefore, future research on cooperation should devote a great deal of effort to promote the making of what he calls an "economic-civil theory of cooperation".

${ }^{7}$ For a discussion of the European reforms introduced in the Nineties - as the 1991 Belgian Law, the 1992 Italian and French Laws, the 1992 Catalonian Law, and the 1993 Basques Law - see the volume edited by Monzon et al. (1996).

${ }^{8}$ Notice that in this example the system of the rule of law is a governance mechanism, whilst its justice is an attribute, a characteristic of this governance mechanism.

${ }^{9}$ Amable et al. (2005) argue that the type of financial relationship between the firm and the capital owner or the financial market will set a certain constraint on firm's profitability, which will partly determine firm’s survival 
probability. This will in turn shape both management and union strategies, hence influencing the outcome of the bargaining between these two actors.

${ }^{10}$ The Italian corporate law disciplines firms' legal structures according to the principle of juristic personality. All legal forms recognized by the Italian lawmaker are present in the Capitalia database, under the classification here presented. A first typology is that of sole trader, a business entity having no separate existence from its owner. Basically, under this legal structure a person does business in his own name and under unlimited liability. Secondly, have partnerships, unincorporated businesses without juristic personality since their legal personality is not separated from that of their members. These enterprises normally operate under the unlimited liability of partners, although other forms (i.e. societa' in accomandita semplice) have evolved in which only certain members have unlimited liability, whilst the others have limited liability. A third legal form is that of corporations, incorporated businesses which are legal entities effectively recognized as a (fictious) person by law. These enterprises are, in other words, juristic persons and operate under limited liability. Fourthly, have cooperative firms, hinging on the principle of mutual aid, which have legal personality and can operate under both limited and unlimited liability. Finally, Capitalia classifies the typologies established lately from the classical forms so far presented under the label "other legal structures", among which figure the s.r.l. unipersonale (an incorporated company having a single owner), societa' di professionisti (professionals' company), and societa' europea (European company).

${ }^{11}$ In this analytical framework, what matters are cooperative firms as a whole, that is as an organizational form having traits that, on one hand, still render it mostly dependent upon banking institutions and, on the other hand, make the bank-firm link complex. Thus, given the purpose of the empirical investigation, possible differentiations in the financial structure of these firms are left aside. Yet, this latter aspect deserves further in depth inquiry, on both theoretical and empirical grounds, in future research.

${ }^{12}$ See Brambol et al. (2006) for an analysis of multiplicative interaction models.

${ }^{13}$ It is worth noting that it has been preferred to control for the sensitivity of sales to inflation, even though in Italy inflation rates are rather contained.

${ }^{14}$ Although Gibrat's law of proportionate effects (1931) states that firm growth is independent of size, empirical research has not reached unequivocal conclusions. Indeed, while most studies rejected the model (Tschoegl, 
1983; Evans, 1987; Dunne et al, 1989; Dunne et al, 1994; Mata, 1994; Weiss, 1998; Audretsch et al, 1999; Becchetti et al, 2002), others found evidence in favor to Gibrat's law (Chen et al, 1985; Kumar, 1985; Acs and Audretsch, 1990; Wagner, 1992; Fulton et al, 1995; Diaz-Hermelo et al, 2004). In between these conclusions, Lotti et al. (2003) find that in some Italian manufacturing industries the behavior of Gibrat's law depends on the life cycle of the firm. In particular, the law does not hold in the first year following start-up, when smaller entrants grow faster in order to achieve a size that enhances their survival likelihood. Thereafter, the law is not rejected, as smaller and larger entrants are not found to follow different growth patterns.

${ }^{15}$ Regarding the relationship between firm age and growth, the general pattern suggested by previous research is that young firms are more likely to grow faster (see, for instance, Glancey, 1998; Almus and Nerlinger, 1999; Wijewardena et al, 1999; Becchetti et al, 2002; Davidsson et al, 2002; Niskanen et al, 2005).

${ }^{16}$ The impact of cash flow on firm growth varies with the availability of external sources of financing, as the latter relax the link between growth and internal finance (Carpenter et al, 2002).

17 This classification of the industrial sectors has been proposed by Pavitt (1984).

${ }^{18}$ The correlation matrix for the variables used in the estimations is reported in the appendix.

${ }^{19}$ An exception to this is represented by the variable COOP and by territorial and sectoral dummies.

${ }^{20}$ Yet, the intention for future research is to dispose of a much greater amount of observations on cooperatives.

${ }^{21}$ Regarding the composition of the sub-sample of cooperatives across the surveys considered in the analysis spanning the triennia 1995-1997, 1998-2000, and 2001-2003 - 61\% firms are present in one wave, 31.6\% are included for six years, hence in two surveys, and 7.4\% firms appear in all three waves. As explained by Attilio Pasetto - in charge for Capitalia’s Indagine sulle imprese manifatturiere - in order to keep in each wave a significant quota of sample units belonging to the preceding surveys, and also to supplement the sample with new units, Capitalia uses the criterion of partial re-sampling of firms (rotation panel design). So that, differences in the firms appearing in the surveys are mainly due to the sampling method adopted. Moreover, as far as nonresponding units are concerned, these include firms that did not adhere to initiatives subsequent to the first one, those that run out of business, those whose number of employees fell below 11, and those not belonging to the manufacturing industry anymore. 
${ }^{22}$ Following Servèn (2003), the criterion used to operate the outliers correction is to consider as outliers all observations for which any of the variables lies beyond 10 standard deviation away from the mean. It is worth mentioning that sole traders have been excluded from the sample as the intention is to focus on enterprises. As regards the category "other legal structures", this has not been considered since it includes very heterogeneous business types (see endnote 10).

${ }^{23}$ The variable PAV2 is not excluded from MOD3, even if not statistically significant, since - as an anonymous referee pointed out - PAV1, PAV2, and PAV3 are to be intended as an integrated set of variables.

${ }^{24}$ Recently, also Fagiolo et al. (2006) found that liquidity constrained firms are those that grow persistently more. The authors show that small and quite dynamic firms are capable to perform well, despite being cash-constrained.

${ }^{25}$ It is important to clarify that it would be erroneous to argue that the more banks are developed, the more firms tend to structure themselves as cooperatives, since this would imply to regard the degree of development of financial intermediaries as driving individuals' organizational choice. And, indeed, the institutional complementarity approach does not conflict with this, since one of its major implications is that the presence of institutional complementarity does not necessarily lead to the selection of a Pareto improving institutional arrangement. In fact, being a dynamic approach admitting multiple equilibria, institutional complementarity - as mentioned in Section 3 - does not rule out that the prevailing institutional arrangements may be Pareto sub-optimal, as well as Pareto non-rankable. This is so because, due to their bounded rationality in perception and choice, agents cannot strategically coordinate their choices across domains, even if they participate in them simultaneously (Aoki, 2001).

${ }^{26}$ The outliers correction for INV has been operated after having estimated the models 1-3. Results are unchanged when these models have been re-estimated after this correction.

${ }^{27}$ It has been argued that employment is a more informative indicator of organizational complexity than sales, and may be preferable if the focus is on the managerial implications of growth (Greiner, 1972; Churchill and Lewis, 1983). Moreover, some scholars have claimed that for resource and knowledge-based views of the firm, which consider firms as bundle of resources, growth analysis should focus on the accumulation of resources, such as employees (Penrose, 1959; Kogut and Zander, 1992).

${ }^{28}$ These figures regard the models from 3 to 7. 


\section{REFERENCES}

Acs, Z. \& Audretsch, D.B. (1990). Small firms and entrepreneurship: a comparison between West and East countries. Discussion Paper, MIT Press.

Alchian, A.A. \& Woodward, S. (1988). Review: The firm is dead; long live the firm a review of Oliver E. Williamson’s The economic institutions of capitalism. Journal of Economic Literature, 26(1), 65-79.

Almus, M. \& Nerlinger, E.A. (1999). Growth of new technology-based firms: which factors matter?. Small Business Economics: An Entrepreneurship Journal, 13(2), 141-154.

Amable, B. (2000). Institutional complementarity and diversity of social systems of innovation and production. Review of International Political Economy, 7, 645-687.

Amable, B., Ernst E. \& Palombarini S. (2005). How do financial markets affect industrial relations: an institutional complementarity approach. Socio-Economic Review, 3(2), 311-330.

Aoki, M. (2001). Toward a comparative institutional analysis. (Cambridge Massachusetts, London: MIT Press).

Ardishvili, A., Cardozo, S., Harmon, S. \& Vadakath, S. (1998, May). Towards a theory of new venture growth. (Paper presented at the 1998 Babson Entrepreneurship Research Conference, Ghent, Belgium).

Audretsch, D.B., Santarelli, E. \& Vivarelli, M. (1999). Start-up size and industrial dynamics: some evidence from Italian manufacturing. International Journal of Industrial Organization, 17, 965-983.

Bartlett, W., Cable, G., Estrin, S., Jones, D.C. \& Smith, S.C. (1992). Labour-managed cooperatives and private firms in North Central Italy: an empirical comparison. Industrial and Labour Relations Review, 46(1), 103-118.

Banerjee, A.V. \& Newman, A.F. (1993). Occupational choice and the process of development. Journal of Political Economy, 101(2), 274-298.

Basili, M., Duranti, C. \& Franzini, M. (2004). Network, trust and institutional complementarities. Rivista di Politica Economica, 1(2), 159-179.

Bayo-Moriones, J.A., Galilea-Salvatierra, P.J. \& Merino-Dìaz de Cerio, J. (2002). Participation, cooperatives and performance: an analysis of Spanish manufacturing firms. (In T. Kato, J. Pliskin (Eds.), The determinants of the incidence and the effects of participatory organisations (pp. 31-56). Amsterdam: Elsevier). 
Becchetti, L. \& Trovato, G. (2002). The determinants of growth for small and medium sized firms. The role of the availability of external finance. Small Business Economics: An Entrepreneurship Journal, 19(4), 291-306.

Beck, T., Demirgüç-Kunt, A. \& Maksimovic, V. (2003). Financial and legal institutions and firm size. Working Paper n. 2997, World Bank Policy Research.

Beck, T., Demirgüç-Kunt, A. \& Maksimovic, V. (2005). Financial and legal constraint to growth. Does size matter?. Journal of Finance, 1(2), 137-177.

Bekaert, G., Harvey, C.H. \& Lundblad, C. (2005). Does financial liberalization spur growth? Journal of Financial Economics, 77, 3-55.

Bencivenga, V. \& Smith, B. (1991). Financial intermediation and endogenous growth. Review of Economic Studies, 58(2), 195-209.

Benfratello, L., Schiantarelli, F. \& Sembenelli, A. (2006). Banks and innovation: microeconometric evidence on Italian firms. Working Paper 631, Boston College.

Ben-Ner, A. (1988). The life cycle of worker-owned firms in market economies: a theoretical analysis. Journal of Economic Behavior and Organization, 10, 287-313.

Blair, M., Kruse, D.L. \& Blasi, J.R. (2000). Employee ownership: an unstable form or a stabilizing force?. (In M. Blair, T. Hockan (Eds.), The new relationship: human capital in the American corporation (pp. 241-298). Washington D.C: Brookings Institution Press).

Bofondi, M. \& Gobbi, G. (2003). Bad loans and entry in local credit markets. Banca d'Italia, Tema di discussione n. 509.

Bonaccorsi di Patti, E. \& Dell’Ariccia, G. (2004). Bank competition and firm creation. Journal of Money, Credit and Banking, 36(2), 225-252.

Bonaccorsi di Patti, E. \& Gobbi, G. (2001a). The changing structure of local credit markets: are small businesses special? Journal of Banking and Finance, 25, 2209-2237.

Bonaccorsi di Patti, E. \& Gobbi, G. (2001b). The effects of bank consolidation and market entry on small business lending. Banca d’Italia, Tema di discussione n. 404. 
Bonin, J., Jones, D.C. \& Putterman, L. (1993). Theoretical and empirical studies of producer cooperatives: will ever the twain meet?. Journal of Economic Literature, 31, 1290-1320.

Boyer, R. (2005). Coherence, diversity, and the evolution of capitalism: the institutional complementary hypothesis. Evolutionary and Institutional Economics Review, 2(1), 43-80.

Brambol, T., Clark, W.R. \& Golder, M. (2006). Understanding interaction models: improving empirical analysis. Political Analysis, 14, 63-82.

Carpenter, R.E. \& Petersen, C. (2002). The growth of small firms constrained by internal finance. The review of Economics and Statistics, 84(2), 298-309.

Cesarini, F. (2003, October). Il rapporto banca-impresa. (Paper presented at the workshop "Impresa, risparmio e intermediazione finanziaria: aspetti economici e profili giuridici”, Trieste).

Chen, K., Babb, E.M. \& Schrader, L.F. (1985). Growth of large cooperative and proprietary firms in the US food sector. Agribusiness, 1, 201-210.

Churchill, C. \& Lewis, V.L. (1983). The five stages of small business growth. Harvard Business Review, 61(3), 30-50.

Cook, M.L. (1995). The future of U.S. agricultural cooperatives: a neo-institutional approach. American Journal of Agricultural Economics, 77, 1153-1159.

Davidsson, P. \& Wiklund, J. (2000). Conceptual and empirical challenges in the study of firm growth. (In D. Sexton, H. Landstrom (Eds.), The Blackwell handbook of entrepreneurship (pp. 26-44). Oxford: Blackwell Publishing).

Davidsson, P., Kirchhoff, B., Hatemi, J.A. \& Gustavsson, H. (2002). Empirical analysis of business growth factors using Swedish data. Journal of Small Business Management, 40(4), 332-349.

Dehejia, R. \& Lleras-Muney, A. (2003). Why does financial development matter? The United States from 1900 to 1940. NBER Working Paper n. 955.

Delmar, F. (1997). Measuring growth: methodological considerations and empirical results. (In R. Donckels, A. Miettinen (Eds.), Entrepreneurship and SME research: on its way to the next millennium (pp. 199-216). Aldershot, Ashgate).

Delmar, F., Daviddson, P. \& Gartner, W.B. (2003). Arriving at the high-growth firms. Journal of Business Venturing, 18, 189-216. 
Demirgüç-Kunt, A. \& Maksimovic, V. (1998). Law, finance, and firm growth. The Journal of Finance, 53(6), 2107-2137.

De Gregorio, J. \& Guidotti, P. (1995). Financial development and economic growth. World Development, 23, 433448.

Dìaz-Hermelo, F. \& Vassolo, R. (2004). The determinants of firm’s growth: an empirical examination. Working Paper, Universidad Austral.

Dixit, A.K. (2007). Economic governance. (In: S. Durlauf, L.E. Blume (Eds.), The New Palgrave Dictionary of Economics, forthcoming, Palgrave Macmillan).

Dow, G. (2003). Governing the firm. (Cambridge: Cambridge University Press).

Drèze, J. (1993). Self-management and economic theory. (In P. Bardhan, J. Roemer (Eds.), Market socialism: the current debate (pp. 253-265). Oxford: Oxford University Press).

Dunne, P. \& Hughes, A. (1994). Age, size, growth and survival: UK companies in the 1980s. Journal of Industrial Economics, 42(2), 115-140.

Dunne, T., Roberts, M.J. \& Samuelson, L. (1989). The growth and failure of US manufacturing plants. Quarterly Journal of Economics, 104(4), 671-698.

Ernst, C.E. (2003, June). Financial systems, industrial relations, and industry specialization. An econometric analysis on institutional complementarities. (In Proceedings of the OeNB Workshop “The Transformation of the European Financial System. Where Do We Go? Where Should We Go?”, Vienna).

Estrin, S. \& Jones, D.C. (1988). The determinants of investments in labor managed firms: evidence from France. Discussion paper n.87, Centre for economic performance, London School of Economics.

Estrin, S. \& Jones, D.C. (1992). The viability of employee-owned firms. Evidence from France. Industrial and Labor relations Review, 45(2), 323-338.

Evans, D.S. (1987). Tests of alternative theories of firm growth. Journal of Political Economy, 95(4), 657-674.

Fagiolo, G. \& Luzzi, A. (2006). Do liquidity constraints matter in explaining firm size and growth? Some evidence from the Italian manufacturing industry. Industrial and Corporate Change, 15(1), 1-39. 
Fernandez, D. \& Galetovic, A. (1994). Schumpeter might be right - but why? Explaining the relation between finance, development and growth. Working Paper, School of Advanced International Studies, John Hopkins University.

Flamholtz, E.G. (1986). Managing the transition from an entrepreneurship to a professionally managed firm. (San Francisco: Jossey-Bass).

Fulton, M.E. (1995). The future of cooperatives in Canada: a property rights approach. American Journal of Agricultural Economics, 77(5), 1144-1152.

Furubotn, E.G. \& Pejovich, S. (1970). Property rights and the behavior of the firm in a socialist state: the example of Yugoslavia. Zeitschrift für Nationalökonomie, 30(5), 431-454.

Gibrat, R. (1931). Les Inegalites Economiques. (Paris: Librairie Du Recueil Sirey).

Glancey, K. (1998). Determinants of growth and profitability in small entrepreneurial firms. International Journal of Entrepreneurial Behaviour and Research, 1(4), 18-27.

Goldsmith, R. (1969). Financial structure and development. (New Haven: Yale University Press).

Greiner, L.E. (1972). Evolutions and revolutions as organizations grow. Harvard Business Review, 50(4), 37-46.

Greenwood, J. \& Jovanovic, B. (1990). Financial development, growth, and the distribution of income. Journal of Political Economy, 98, 1076-1107.

Guiso, L., Sapienza, P. \& Zingales, L. (2004). Does local financial development matter?. The Quarterly Journal of Economics, 119(3), 929-969.

Hall, P.A. \& Gingerich, D.W. (2004). Varieties of capitalism and institutional complementarities in the macroeconomy. An empirical analysis. Discussion Paper n. 04/5, Max Planck Institute for the Study of Societies.

Hoy, F., McDougall, P.P. \& Dsouza, D.E. (1992). Strategies and environments of high growth firms. (In: D.L. Sexton, J.D. Kasarda (Eds.), The state of the art of entrepreneurship (pp. 341-357). Boston: PWS-Kent Publishing).

Jayaratne, J. \& Strahan, P.E. (1996). The finance-growth nexus: evidence from bank branch deregulation. Quarterly Journal of Economics, 111, 639-670. 
Jensen, M.C. \& Meckling, W.R. (1976). Theory of the firm: managerial behaviour, agency costs and capital structure. Journal of Financial Economics, 3(4), 305-360.

Jossa, B., Cuomo, G. (1997). The economic theory of socialism and the labour-managed firm. Market, socialism and labour management. (Edward Elgar Publishers: Cheltenham-Brookfield).

King R. \& Levine, R. (1993). Finance and growth: Schumpeter might be right. Quarterly Journal of Economics, 108, 717-738.

Kogut, B. \& Zander, U. (1992). Knowledge of the firm, combinative capabilities, and the replication of technology. Organization Science, 3(3), 383-397.

Kumar, M.S. (1985). Growth, acquisition activity and firm size: evidence from the United Kingdom. Journal of Industrial Economics, 33(3), 327-338.

Kwast, M., Starr-McCluer, M. \& Wolken, J. (1997). Market definition and the analysis of antitrust in banking. The Antitrust Bulletin, 42, 973-995.

La Loggia Albanese, E. (2003). Titoli di partecipazione nelle societa’ cooperative. Rivista di diritto dell'economia, dei trasporti e dell'ambiente, 1,111-123.

Levin, H.M. (1984). ESOPs and the financing of worker cooperatives. (In R. Jackall, H.M. Levin (Eds.), Worker cooperatives in America (pp. 220-245). Berkeley: University of California Press).

Levine, R. (1992). Financial structure and economic development. Working Paper n. 849, the World Bank.

Levine, R. (1997). Financial development and economic growth: views and agenda. Journal of Economic Literature, 35, 688-726.

Levine, R. \& Zervos, S. (1998). Stock markets, banks, and economic growth. American Economic Review, 88, 537-558.

Lotti, F., Santarelli, E. \& Vivarelli, M. (2003). Does Gibrat's law hold among young, small firms? Journal of Evolutionary Economics, 13, 213-235.

Mata, J. (1994). Firm growth during infancy. Small Business Economics: An Entrepreneurship Journal, 6(1), 27-40. 
Mathews, R. (2002, October). Mondragòn: past performance and future potential. (Paper presented at the Capital Ownership Group Conference, the Kent State University, Washington).

Ménard, C. (2004). The economics of hybrid organizations. Journal of Institutional and Theoretical Economics, $160,345-376$.

Monzon, J.L., Spear-Thomas, A. \& Zevi, A. (Eds.). (1996). Cooperatives, Markets and Cooperative Principles. (Liège: International Ciriec Association Press).

Myers, S.C. \& Majluf, N.S. (1984). Corporate financing and investment decisions when firms have information that investors do not have. Journal of Financial Economics, 13(2), 187-221.

McKinnon, R. (1973). Money and capital in economic development. (Washington D.C: Brooking Institutions).

Nicita, A., Pagano, U. (2004). Institutional complementarities, corporate governance and financial-technological equilibria. Siena memos and papers on law and economics n.28, Università di Siena.

Niskanen, M. \& Niskanen, J. (2005). The determinants of firm growth in small and micro firms - Evidence on relationship lending effects. Working Paper, University of Kuopio.

Onida, F. (2004). Se il piccolo non cresce. Piccole e medie imprese italiane in affanno. (Bologna: Il Mulino).

Pavitt, K. (1984). Patterns of technical change: towards a taxonomy and a theory. Research Policy, 13, 343-373.

Pejovich, S. (1969). The firm, monetary policy and property rights in a planned economy. Western Economic Journal, 7(3), 193-200.

Pejovich, S. (1992). Why has the labor-managed firm failed?. Cato Journal, 12(2), 461-473.

Penrose, E. (1959). The theory of the growth of the firm. (Oxford: Oxford University Press).

Petersen, M.A. \& Rajan, R.G. (2002). Does distance still matter? The information revolution in small business lending. Journal of Finance, 57(6), 2533-2570.

Putterman, L. (1982). Some behavioral perspectives on the dominance of hierarchical over democratic forms of enterprise. Journal of Economic Behavior and Organization, 3, 139-160.

Putterman, L. (1993). Ownership and the nature of the firm. Journal of Comparative Economics, 17(2), 243-263. 
Rajan, R.G. \& Zingales, L. (1998). Financial dependence and growth. American Economic Review, 88, 559-586.

Saint-Paul, G. (1992). Technological choice, financial markets and economic development. European Economic Review, 36(4), 763-781.

Salani, M.P. (2005). Le basi istituzionali della forma cooperativa. (In E. Mazzoli, S. Zamagni (Eds.), Verso una nuova teoria economica della cooperazione (pp. 141-223). Bologna: Il Mulino).

Schlicht, E., von Weizsäcker, C.C. (1977). Risk financing in labour-managed economies: the commitment problem. Zeitschrift für die gesamte staatswissenschaft, 133, 53-66.

Servèn, L. (2003). Real exchange rate uncertainty and private investment in LDCs. Review of Economic and Statistics, 88(1), 212-218.

Shaw, E. (1973). Financial deepening in economic development. (New York: Oxford University Press).

Smith, S.C. (2001). Blooming together or wilting alone? Network externalities and Mondragòn and La Lega cooperative networks. Discussion Paper n. 2001/27, World Institute for Development Economics Research, United Nations University.

Staber, U. (1989). Age dependence and historical effects on the failure rates of worker cooperatives: an event history analysis. Economic and Industrial Democracy, 10(1), 59-80.

Stephen, F.H. (1984). The economic analysis of producers' cooperatives. (London, McMillan).

Stiglitz, J. (2004). The role of cooperatives in globalization. Working Paper n. 9, University of Genova.

Stiglitz, J.S. \& Weiss, A. (1981). Credit rationing in markets with imperfect information. American Economic Review, 71(3), 393-410.

Sutton, J. (1997). Gibrat’s legacy. Journal of Economic Literature, 35, 40-59.

Tschoegl, A.E. (1983). Size, growth, and transnationality among the world's largest banks. Journal of business, 56(2), 187-201.

Vanek, J. (1970). The general theory of labor managed market economies. (Ithaca, New York: Cornell University Press).

Vanek, J. (1977). The labor-managed economy. (Ithaca, New York: Cornell University Press). 
Vitaliano, P. (1983). Cooperative enterprise: an alternative conceptual basis for analyzing a complex institution. American Journal of Agricultural Economics, 65(5), 1078-1083.

Wagner, J. (1992). Firm size, firm growth, and persistence of chance: testing Gibrat's law with establishment data from Lower Saxony, 1978-1989. Small Business Economics: An Entrepreneurship Journal, 42(2), 125-131.

Weiss, C.R. (1998). Size, growth, and survival in the upper Austrian farm sector. Small Business Economics: An Entrepreneurship Journal, 10(4), 305-312.

Wijewardena, H. \& Tibbits, G.E. (1999). Factors contributing to the Growth of Small Manufacturing Firms: Data from Australia. Journal of Small Business Management, 37(20), 38-45.

Williamson, O.E. (1988), Corporate finance and corporate governance. Journal of Finance, 43 (3), 576-591.

Zamagni, S. (2005). Per una teoria economico-civile dell’impresa cooperativa. (In E. Mazzoli, S. Zamagni (Eds.), Verso una nuova teoria economica della cooperazione (pp. 15-56). Bologna: Il Mulino).

Zevi, A. (2005). Il finanziamento delle cooperative. (In E. Mazzoli, S. Zamagni (Eds.), Verso una nuova teoria economica della cooperazione (pp. 293-331). Bologna: Il Mulino). 
Channels through which financial development impacts on the economy

Goldsmith (1969), Greenwood et al . (1990), Fernandez et al . (1994)

Better screening and monitoring of inve-

stors by banks increase the marginal pro-

ductivity of capital, hence the efficiency of

investments
Better accounting and disclosure rules, and better corporate governance through institutions, lower the costs of raising fu from, mostly reliant on external financing
Rajan and Zingales (1998) Benfratello et al . (2006)

McKinnon (1973), Shaw (1973) Bencivenga et al . (1991)

Levine (1992), Saint-Paul (1992)
Greater credit availability, which increases investments level, since individuals and firms are insured against the risks associated with heir liquidity needs

\section{EMPIRICAL STUDIES}

\section{Level and area of analysis}

Jayaratne et al . (1996)

United States (50 states) during the period 1972-1992

Micro-level analysis on a sample of 30

Demirgüç-Kunt et al . (1998) countries over the period 1980-1991

\section{Measure of financial development}

Bank branching deregulation measured through an indicator of intrastate branch reform equal to 1 for states without restrictions on branching via mergers and acquisitions

A financial planning model predicts the max growth rate firms can attain withou term external financing. These rates are then compared with those realised by fims in countries with different degrees of fins cial development

\section{Main finding}

Improvement in bank lending quality is the main channel through which the American intrastate branching reform influenced economic growth

Firms operating in countries having active and more developed financial markets are Fet rnal finance and 


\section{EMPIRICAL STUDIES}

\section{Level and area of analysis}

Dehejia et al . (2003)

United States during 1900-1940

Firm-level survey database covering 44 countries for the period 1988-1997

Beck et al . (2003)

Beck et al . (2005)

Guiso et al . (2004)

Benfratello et al . (2006)

Firm-level survey database covering 54 countries for the period 1995-1999

Regional level analysis on Italian data for the period 1989-1997

Provincial level analysis on Italy for the

\section{Measure of financial development}

Level and growth of state bank loans

Claims of deposit money banks on the private sector as share of GDP, as a measure for financial intermediary development. Value of outstanding shares on GDP, measuring stock market development period 1992-2000

\section{(1)}

Domestic bank credit to the private sector on GDP

Local indicator measuring how much more likely an individual is to obtain credit in region, rather than in another one

Branch density, measured as number of bank branches over population

\section{Main finding}

By improving lending quality, banking development facilitates the shift from agriculture to manufacture, has a positive impact on human capital accumulation and on wealth acquisition

Banking development is positively related to firm size. This relationship is stronger for firms more dependent on external financing

Financial and institutional development weakens the constraining effects of financial, legal and corruption obstacles to firm growth, particularly for small firms

Financial development stimulates entrepreneurship, firm growth and the creation of wealth

Local banking development has a positive impact on firm innovative activity, especially for small firms strongly dependent on external finance 


\begin{tabular}{ll}
\hline Variable & Description \\
\hline GROWTH & Firm's annual growth rate of real sales \\
EMPLOY & Firm's number of employees \\
SIZE & Firm's total assets \\
AGE & Firm age measured as current year minus year of establishment \\
CASHFLOW & Firm's declared income plus depreciation and quiescence fund scaled by total assets \\
BANKDEBT & Short and long-term bank loans on firm's total assets \\
INV & Investments in installation, machinery, and equipment on total assets \\
BRANCH & Number of bank branches operating in a province normalised by population, scaled by 10000 \\
COOP & Dummy variable which takes on the value of 1 if firm is a cooperative and 0 otherwise \\
GRU & Dummy variable which takes on the value of 1 if firm belongs to a group and 0 otherwise \\
POP & Provincial population \\
RPI & Provincial real per capita income \\
CEN-NORTH & Dummy variable which takes on the value of 1 if firm operates in a Centre Northern province and 0 otherwise \\
SOUTH & Dummy variable which takes on the value of 1 if firm operates in a Southern province and 0 otherwise \\
PAV1 & Dummy variable which takes on the value of 1 if firm operates in the supplier dominated sector and 0 otherwise \\
PAV2 & Dummy variable which takes on the value of 1 if firm operates in the scale intensive sector and 0 otherwise \\
PAV3 & Dummy variable which takes on the value of 1 if firm operates in the specialised suppliers sector and 0 otherwise \\
PAV4 & Dummy variable which takes on the value of 1 if firm operates in the science based sector and 0 otherwise \\
& \\
\hline All variables are drawn from Capitalia except for: i) BRANCH, obtained by calculations on data ISTAT and Bank of Italy, ii) RPI and POP which are \\
drawn from ISTAT.
\end{tabular}

TABLE 3 - Summary statistics

\begin{tabular}{lccccc}
\hline & & & & & \\
Variable & Obs & Mean & Std. Dev. & Min & Max \\
\hline GROWTH $^{*}$ & 17479 & 3.35 & 17.21 & -44.99 & 105.33 \\
EMPLOY $^{*}$ & 17477 & 79 & 158 & 11 & 2,200 \\
SIZE $^{*}$ & 15570 & 8,194 & 20,941 & 12 & 376,483 \\
AGE $^{++}$ & 17479 & 24 & 17 & 0 & 191 \\
CASHFLOW $^{*}$ & 15570 & 12.99 & 8.27 & -62.14 & 69.98 \\
BANKDEBT $^{*}$ & 15570 & 16.51 & 17.90 & 0.00 & 89.78 \\
INV $^{*}$ & 12893 & 9.712 & 11.433 & 0 & 77.09 \\
BRANCH & 17479 & 5.8423 & 1.4650 & 1.5531 & 10.2865 \\
COOP $_{\text {GRU }}$ & 17479 & 0.0326 & 0.1775 & 0 & 1 \\
POP & 17479 & 0.2279 & 0.4195 & 0 & 1 \\
RPI & 17479 & $1,050,100$ & $1,068,675$ & 89,775 & $3,775,765$ \\
CEN-NORTH & 17479 & 21.4862 & 4.7012 & 9.3096 & 31.9725 \\
SOUTH & 17479 & 0.8595 & 0.3475 & 0 & 1 \\
PAV1 & 17479 & 0.1405 & 0.3475 & 0 & 1 \\
PAV2 & 17479 & 0.5147 & 0.4998 & 0 & 1 \\
PAV3 & 17479 & 0.1767 & 0.3814 & 0 & 1 \\
PAV4 & 17479 & 0.2577 & 0.4374 & 0 & 1 \\
& 17479 & 0.0509 & 0.2197 & 0 & 1 \\
\hline
\end{tabular}

For the description of the variables see table 2. *In percentage terms; ${ }^{*}$ In thousands of Euro; ${ }^{+}$In units; ${ }^{++}$ Years. All the other variables are dummies, with the exception of BRANCH (see table 2). 
TABLE 4 - Estimation results

Dependent variable: GROWTH

\begin{tabular}{|c|c|c|c|}
\hline & MOD 1 & MOD 2 & MOD 3 \\
\hline \multirow[t]{2}{*}{ EMPLOY } & -0.0019 & -0.0019 & -0.0019 \\
\hline & 0.0500 & 0.0490 & 0.0490 \\
\hline \multirow[t]{2}{*}{ AGE } & -0.0334 & -0.0335 & -0.0332 \\
\hline & 0.0010 & 0.0010 & 0.0010 \\
\hline \multirow[t]{2}{*}{ CASHFLOW } & -0.1094 & -0.1094 & -0.1095 \\
\hline & 0.0000 & 0.0000 & 0.0000 \\
\hline \multirow[t]{2}{*}{ BANKDEBT } & 0.0204 & 0.0204 & 0.0203 \\
\hline & 0.0510 & 0.0520 & 0.0520 \\
\hline \multirow[t]{2}{*}{ BRANCH } & 0.4393 & 0.4282 & 0.3417 \\
\hline & 0.0270 & 0.0250 & 0.0220 \\
\hline \multirow[t]{2}{*}{ COOP } & -5.1204 & -5.0433 & -5.1618 \\
\hline & 0.0840 & 0.0860 & 0.0780 \\
\hline \multirow[t]{2}{*}{ INTE } & 1.0160 & 1.0053 & 1.0238 \\
\hline & 0.0380 & 0.0390 & 0.0360 \\
\hline \multirow[t]{2}{*}{ GRU } & 1.4625 & 1.4692 & 1.4710 \\
\hline & 0.0010 & 0.0010 & 0.0010 \\
\hline \multirow[t]{2}{*}{ POP } & 0.1886 & 0.2079 & \\
\hline & 0.5460 & 0.4850 & \\
\hline \multirow[t]{2}{*}{ RPI } & -0.1611 & -0.1709 & -0.1393 \\
\hline & 0.0360 & 0.0080 & 0.0030 \\
\hline \multirow[t]{2}{*}{ CEN-NORTH } & -0.1862 & & \\
\hline & 0.8270 & & \\
\hline \multirow[t]{2}{*}{ PAV1 } & -2.6168 & -2.6157 & -2.6452 \\
\hline & 0.0040 & 0.0040 & 0.0030 \\
\hline \multirow[t]{2}{*}{ PAV2 } & -0.6900 & -0.6925 & -0.6917 \\
\hline & 0.4590 & 0.4580 & 0.4580 \\
\hline \multirow[t]{2}{*}{ PAV3 } & -1.6715 & -1.6715 & -1.6780 \\
\hline & 0.0690 & 0.0690 & 0.0680 \\
\hline \multirow[t]{2}{*}{ LM Test } & 0.03 & 0.02 & 0.03 \\
\hline & 0.8731 & 0.8752 & 0.8710 \\
\hline \multirow[t]{2}{*}{ Model Test } & 25.32 & 26.62 & 28.05 \\
\hline & 0.0000 & 0.0000 & 0.0000 \\
\hline R-squared & 0.0452 & 0.0452 & 0.0452 \\
\hline \multirow{2}{*}{ F Test (BRANCH INTE) } & 5.430 & 5.730 & 5.960 \\
\hline & 0.0044 & 0.0033 & 0.0026 \\
\hline N. OBS & 10,202 & 10,202 & 10,203 \\
\hline
\end{tabular}

For the description of the variables see table 2. In italics are reported the p-values of the tests. The $t$ statistics (not reported) are based on robust standard errors. INTE is the interaction term between BRANCH and COOP. With exception of this latter, and of territorial and industrial dummies, all the explanatory variables have been lagged once, to avoid simultaneity. The variable POP is taken in logarithm terms. Time dummies and constant included but not reported. LM test is the Breusch and Pagan Lagrange Multiplier test for random effects. $F$ test is a test of joint significance of the variables indicated in round brackets. From MOD 1 to MOD 3 the general-to-simple procedure has been applied. 
TABLE 5 - Robustness: checking for endogeneity and including new regressors

\begin{tabular}{|c|c|c|c|}
\hline \multicolumn{4}{|c|}{ Dependent variable: GROWTH } \\
\hline \multirow{3}{*}{ EMPLOY } & $\begin{array}{c}\text { MOD } 3 \\
\text { (Endogeneity check) }\end{array}$ & MOD 4 & $\begin{array}{c}\text { MOD } 4 \\
\text { (Endogeneity check) }\end{array}$ \\
\hline & -0.0030 & -0.0022 & -0.0025 \\
\hline & 0.0330 & 0.0280 & 0.0850 \\
\hline \multirow[t]{2}{*}{ AGE } & -0.0312 & -0.0307 & -0.0265 \\
\hline & 0.0470 & 0.0040 & 0.1130 \\
\hline \multirow[t]{2}{*}{ CASHFLOW } & -0.0502 & -0.1628 & -0.1057 \\
\hline & 0.2570 & 0.0000 & 0.0780 \\
\hline \multirow[t]{2}{*}{ INV } & & 0.0868 & 0.0470 \\
\hline & & 0.0000 & 0.4250 \\
\hline \multirow[t]{2}{*}{ BANKDEBT } & 0.0306 & 0.0282 & 0.0280 \\
\hline & 0.0920 & 0.0170 & 0.1780 \\
\hline \multirow[t]{2}{*}{ BRANCH } & 0.5197 & 0.3354 & 0.7099 \\
\hline & 0.1840 & 0.0400 & 0.1150 \\
\hline \multirow[t]{2}{*}{ COOP } & -0.1849 & -6.2213 & -1.9194 \\
\hline & 0.9710 & 0.0750 & 0.7620 \\
\hline \multirow[t]{2}{*}{ INTE } & 0.3242 & 1.0661 & 0.4618 \\
\hline & 0.6940 & 0.0600 & 0.6510 \\
\hline \multirow[t]{2}{*}{ GRU } & 1.3665 & 1.1718 & 1.0709 \\
\hline & 0.0360 & 0.0120 & 0.1210 \\
\hline \multirow[t]{2}{*}{ RPI } & -0.1939 & -0.1664 & -0.2869 \\
\hline & 0.0220 & 0.0010 & 0.0020 \\
\hline \multirow[t]{2}{*}{ PAV1 } & -2.1004 & -2.5744 & -1.2849 \\
\hline & 0.0920 & 0.0040 & 0.3070 \\
\hline \multirow[t]{2}{*}{ PAV2 } & -0.2441 & -0.5146 & 0.5879 \\
\hline & 0.8510 & 0.5850 & 0.6540 \\
\hline \multirow[t]{2}{*}{ PAV3 } & -1.3185 & -1.2229 & -0.4833 \\
\hline & 0.3010 & 0.1870 & 0.7080 \\
\hline \multirow[t]{2}{*}{ LM Test } & & 0.31 & \\
\hline & & 0.5762 & \\
\hline \multirow[t]{2}{*}{ Model Test } & 13.74 & 25.93 & 10.97 \\
\hline & 0.0000 & 0.0000 & 0.0000 \\
\hline \multicolumn{2}{|l|}{ R-squared } & 0.0594 & \\
\hline UN R-squared & 0.0505 & & 0.0646 \\
\hline F Test (BRANCH INTE) & & $\begin{array}{c}4.81 \\
0.0081\end{array}$ & \\
\hline \multicolumn{4}{|l|}{ Tests of endogeneity: } \\
\hline \multirow[t]{2}{*}{ Wu-Hausman F test: } & 0.5904 & & 0.6565 \\
\hline & 0.6213 & & 0.6223 \\
\hline \multirow[t]{2}{*}{ Durbin-Wu-Hausman test } & 1.7777 & & 2.6400 \\
\hline & 0.6198 & & 0.6198 \\
\hline \multirow{2}{*}{$\begin{array}{l}\text { Hansen-Sargan statistic } \\
\text { (overidentification test of all } \\
\text { instruments) }\end{array}$} & 1.765 & & 4.375 \\
\hline & 0.4138 & & 0.1122 \\
\hline N. OBS & 5,205 & 7,988 & 3,858 \\
\hline
\end{tabular}

For the description of the variables see table 2. In italics are reported the p-values of the tests. The $t$ statistics (not reported) are based on robust standard errors. INTE is the interaction term between BRANCH and COOP. With exception of this latter, and of territorial and industrial dummies, all the explanatory variables have been lagged once, to avoid simultaneity. Time dummies and constant included but not reported. LM test is the Breusch and Pagan Lagrange multiplier test for random effects. $F$ test is a test of joint significance of the variables indicated in round brackets. The tests of endogeneity for the estimations on MOD 3 regard the variables BRANCH, BANKDEBT, CASHFLOW, whilst those for the estimations on MOD 4 are for the variables BRANCH, BANKDEBT, CASHFLOW and INV. In the first case, the instruments used are: the provincial area in square kilometers (AREA), the number of municipalities (MUNI), the dummy CEN-NORTH, one lag of BANKDEBT and one lag of CASHFLOW. In the second case the instruments include also one lag of the variable INV. 
TABLE 6 - Robustness: changing the dependent variable

Dependent variable: GROWTH2

\begin{tabular}{|c|c|c|c|}
\hline \multirow[b]{2}{*}{ EMPLOY } & MOD 5 & MOD 6 & MOD 7 \\
\hline & & & $\begin{array}{l}-0.0024 \\
0.0100\end{array}$ \\
\hline \multirow[t]{2}{*}{ SIZE1 } & 0.2754 & & \\
\hline & 0.0880 & & \\
\hline \multirow[t]{2}{*}{ SIZE2 } & & 0.2618 & \\
\hline & & 0.0890 & \\
\hline \multirow[t]{2}{*}{ AGE } & -0.0568 & -0.0576 & -0.0483 \\
\hline & 0.0000 & 0.0000 & 0.0000 \\
\hline \multirow[t]{2}{*}{ CASHFLOW } & -0.0391 & -0.0370 & -0.0395 \\
\hline & 0.0580 & 0.0740 & 0.0540 \\
\hline \multirow[t]{2}{*}{ INV } & 0.0471 & 0.0474 & 0.0464 \\
\hline & 0.0020 & 0.0020 & 0.0020 \\
\hline \multirow[t]{2}{*}{ BANKDEBT } & 0.0076 & 0.0074 & 0.0127 \\
\hline & 0.4480 & 0.4630 & 0.1930 \\
\hline \multirow[t]{2}{*}{ BRANCH } & 0.3941 & 0.3945 & 0.3621 \\
\hline & 0.0270 & 0.0270 & 0.0420 \\
\hline \multirow[t]{2}{*}{ COOP } & -10.211 & -10.359 & -10.768 \\
\hline & 0.0030 & 0.0030 & 0.0020 \\
\hline \multirow[t]{2}{*}{ INTE } & 1.8152 & 1.8356 & 1.9229 \\
\hline & 0.0010 & 0.0010 & 0.0010 \\
\hline \multirow[t]{2}{*}{ GRU } & 0.1533 & 0.1482 & 0.8764 \\
\hline & 0.7080 & 0.7190 & 0.0260 \\
\hline \multirow[t]{2}{*}{ POP } & 0.4989 & 0.4921 & 0.4920 \\
\hline & 0.0850 & 0.0890 & 0.0900 \\
\hline \multirow[t]{2}{*}{ RPI } & -0.1903 & -0.1898 & -0.1915 \\
\hline & 0.0080 & 0.0080 & 0.0070 \\
\hline \multirow[t]{2}{*}{ CEN-NORTH } & 0.0482 & 0.1044 & 0.2240 \\
\hline & 0.9520 & 0.8960 & 0.7800 \\
\hline \multirow[t]{2}{*}{ PAV1 } & -0.4492 & -0.4243 & -0.5055 \\
\hline & 0.4760 & 0.5010 & 0.4220 \\
\hline \multirow[t]{2}{*}{ PAV2 } & 0.2694 & 0.2894 & 0.2082 \\
\hline & 0.6960 & 0.6750 & 0.7620 \\
\hline \multirow[t]{2}{*}{ PAV3 } & -0.0417 & -0.0260 & -0.0442 \\
\hline & 0.9480 & 0.9670 & 0.9450 \\
\hline \multirow[t]{2}{*}{ LM Test } & 0.550 & 0.540 & 0.590 \\
\hline & 0.4577 & 0.4605 & 0.4442 \\
\hline \multirow[t]{2}{*}{ Model Test } & 7.03 & 6.99 & 6.97 \\
\hline & 0.0000 & 0.0000 & 0.0000 \\
\hline R-squared & 0.0294 & 0.0293 & 0.030 \\
\hline \multirow{2}{*}{ F Test (BRANCH INTE) } & 8.96 & 9.08 & 9.22 \\
\hline & 0.0001 & 0.0001 & 0.0001 \\
\hline N. OBS & 4,065 & 4,065 & 4,065 \\
\hline
\end{tabular}

For the description of the variables see table 2. In italics are reported the p-values of the tests. The $t$ statistics (not reported) are based on robust standard errors. GROWTH2 is the annual growth rate of employees. SIZE1 is the log of real sales, while SIZE2 is the log of total assets. INTE is the interaction term between BRANCH and COOP. With exception of this latter, and of territorial and industrial dummies, all the explanatory variables have been lagged once, to avoid simultaneity. Time dummies and constant included but not reported. LM test is the Breusch and Pagan Lagrange multiplier test for random effects. $F$ test is a test of joint significance of the variables indicated in round brackets. 
TABLE 7 - Robustness: clustering on provinces

DEPENDENT VARIABLE

\section{GROWTH}

GROWTH 2

\begin{tabular}{|c|c|c|c|c|c|}
\hline & $\begin{array}{c}\text { (on) } \\
\text { MOD } 3\end{array}$ & $\begin{array}{c}\text { (on) } \\
\text { MOD } 4\end{array}$ & $\begin{array}{c}\text { (on) } \\
\text { MOD } 5\end{array}$ & $\begin{array}{c}\text { (on) } \\
\text { MOD } 6\end{array}$ & $\begin{array}{c}\text { (on) } \\
\text { MOD } 7\end{array}$ \\
\hline EMPLOY & $\begin{array}{c}-0.0019 \\
0.0480\end{array}$ & $\begin{array}{c}-0.0022 \\
0.0350\end{array}$ & & & $\begin{array}{c}-0.0024 \\
0.0180\end{array}$ \\
\hline SIZE1 & & & $\begin{array}{l}0.2754 \\
0.1480\end{array}$ & & \\
\hline SIZE2 & & & & $\begin{array}{l}0.2618 \\
0.1380\end{array}$ & \\
\hline AGE & $\begin{array}{c}-0.0332 \\
0.0010\end{array}$ & $\begin{array}{c}-0.0307 \\
0.0010\end{array}$ & $\begin{array}{c}-0.0568 \\
0.0000\end{array}$ & $\begin{array}{c}-0.0576 \\
0.0000\end{array}$ & $\begin{array}{c}-0.0483 \\
0.0000\end{array}$ \\
\hline CASHFLOW & $\begin{array}{l}-0.1095 \\
0.0000\end{array}$ & $\begin{array}{c}-0.1628 \\
0.0000\end{array}$ & $\begin{array}{c}-0.0391 \\
0.0630\end{array}$ & $\begin{array}{c}-0.0370 \\
0.0780\end{array}$ & $\begin{array}{c}-0.0395 \\
0.0530\end{array}$ \\
\hline INV & & $\begin{array}{l}0.0868 \\
0.0000\end{array}$ & $\begin{array}{l}0.0471 \\
0.0060\end{array}$ & $\begin{array}{l}0.0474 \\
0.0060\end{array}$ & $\begin{array}{l}0.0464 \\
0.0070\end{array}$ \\
\hline BANKDEBT & $\begin{array}{l}0.0203 \\
0.0500\end{array}$ & $\begin{array}{l}0.0282 \\
0.0100\end{array}$ & $\begin{array}{l}0.0076 \\
0.3710\end{array}$ & $\begin{array}{l}0.0074 \\
0.3870\end{array}$ & $\begin{array}{l}0.0127 \\
0.1340\end{array}$ \\
\hline BRANCH & $\begin{array}{l}0.3417 \\
0.0140\end{array}$ & $\begin{array}{l}0.3354 \\
0.0200\end{array}$ & $\begin{array}{l}0.3941 \\
0.0670\end{array}$ & $\begin{array}{l}0.3945 \\
0.0670\end{array}$ & $\begin{array}{l}0.3621 \\
0.0960\end{array}$ \\
\hline COOP & $\begin{array}{c}-5.1618 \\
0.0870\end{array}$ & $\begin{array}{c}-6.2213 \\
0.0890\end{array}$ & $\begin{array}{c}-10.211 \\
0.0070\end{array}$ & $\begin{array}{c}-10.359 \\
0.0060\end{array}$ & $\begin{array}{c}-10.768 \\
0.0040\end{array}$ \\
\hline INTE & $\begin{array}{l}1.0238 \\
0.0330\end{array}$ & $\begin{array}{l}1.0661 \\
0.0710\end{array}$ & $\begin{array}{l}1.8152 \\
0.0040\end{array}$ & $\begin{array}{l}1.8356 \\
0.0030\end{array}$ & $\begin{array}{l}1.923 \\
0.0020\end{array}$ \\
\hline GRU & $\begin{array}{l}1.4710 \\
0.0000\end{array}$ & $\begin{array}{l}1.1718 \\
0.0110\end{array}$ & $\begin{array}{l}0.1533 \\
0.7090\end{array}$ & $\begin{array}{l}0.1482 \\
0.7280\end{array}$ & $\begin{array}{l}0.8764 \\
0.0200\end{array}$ \\
\hline POP & & & $\begin{array}{l}0.4989 \\
0.1130\end{array}$ & $\begin{array}{l}0.4921 \\
0.1190\end{array}$ & $\begin{array}{l}0.4920 \\
0.1250\end{array}$ \\
\hline RPI & $\begin{array}{l}-0.1393 \\
0.0000\end{array}$ & $\begin{array}{c}-0.1664 \\
0.0000\end{array}$ & $\begin{array}{c}-0.1903 \\
0.0090\end{array}$ & $\begin{array}{l}-0.1898 \\
0.0090\end{array}$ & $\begin{array}{c}-0.1915 \\
0.0090\end{array}$ \\
\hline CEN-NORTH & & & $\begin{array}{l}0.0482 \\
0.9490\end{array}$ & $\begin{array}{l}0.1044 \\
0.8890\end{array}$ & $\begin{array}{l}0.2240 \\
0.7700\end{array}$ \\
\hline PAV1 & $\begin{array}{c}-2.6452 \\
0.0000\end{array}$ & $\begin{array}{c}-2.5744 \\
0.0000\end{array}$ & $\begin{array}{c}-0.4492 \\
0.4370\end{array}$ & $\begin{array}{l}-0.4243 \\
0.4600\end{array}$ & $\begin{array}{c}-0.5055 \\
0.3870\end{array}$ \\
\hline PAV2 & $\begin{array}{c}-0.6917 \\
0.3530\end{array}$ & $\begin{array}{c}-0.5146 \\
0.4950\end{array}$ & $\begin{array}{l}0.2694 \\
0.6480\end{array}$ & $\begin{array}{l}0.2894 \\
0.6250\end{array}$ & $\begin{array}{l}0.2082 \\
0.7300\end{array}$ \\
\hline PAV3 & $\begin{array}{c}-1.6780 \\
0.0240\end{array}$ & $\begin{array}{c}-1.2229 \\
0.0720\end{array}$ & $\begin{array}{c}-0.0417 \\
0.9450\end{array}$ & $\begin{array}{c}-0.0260 \\
0.9660\end{array}$ & $\begin{array}{c}-0.0442 \\
0.9420\end{array}$ \\
\hline Model Test & $\begin{array}{l}32.39 \\
0.0000\end{array}$ & $\begin{array}{l}24.96 \\
0.0000\end{array}$ & $\begin{array}{c}9.48 \\
0.0000\end{array}$ & $\begin{array}{c}9.00 \\
0.0000\end{array}$ & $\begin{array}{c}8.11 \\
0.0000\end{array}$ \\
\hline R-squared & 0.0452 & 0.0594 & 0.0294 & 0.0293 & 0.03 \\
\hline F Test (BRANCH INTE) & $\begin{array}{c}7.78 \\
0.0007\end{array}$ & $\begin{array}{c}5.01 \\
0.0085\end{array}$ & $\begin{array}{c}7.96 \\
0.0006\end{array}$ & $\begin{array}{c}8.09 \\
0.0006\end{array}$ & $\begin{array}{c}8.45 \\
0.0004\end{array}$ \\
\hline N. OBS & 10,203 & 7,988 & 4,065 & 4,065 & 4,065 \\
\hline
\end{tabular}

For the description of the variables see table 2. In italics are reported the p-values of the tests. The t statistics (not reported) are based on robust standard errors adjusted for clustering on provinces. GROWTH is the annual growth rate of real sales, and GROWTH2 is the annual growth rate of employees. SIZE1 is the log of real sales, while SIZE2 is the log of total assets. INTE is the interaction term between BRANCH and COOP. With exception of this latter, and of territorial and industrial dummies, all the explanatory variables have been lagged once, to avoid simultaneity. The variable POP is taken in logarithm terms. Time dummies and constant included but not reported. $F$ test is a test of joint significance of the variables indicated in round brackets. 
TABLE 8 - The impact of BRANCH on GROWTH when COOP=1

\begin{tabular}{lccc} 
& MOD 3 & MOD 4 & MOD 5 \\
Est. coeff. of BRANCH (1) & 0.4393 & 0.3354 & 0.3941 \\
Est. coeff. of INTE (2) & 1.0160 & 1.0661 & 1.8152 \\
& & & \\
Var of (1) & $2.22 \mathrm{E}-02$ & $2.66 \mathrm{E}-02$ & $3.18 \mathrm{E}-02$ \\
Var of (2) & $2.37 \mathrm{E}-01$ & $3.21 \mathrm{E}-01$ & $3.17 \mathrm{E}-01$ \\
COV. (1) (2) & $-1.37 \mathrm{E}-02$ & $-1.79 \mathrm{E}-02$ & $-1.55 \mathrm{E}-02$ \\
& & & \\
t-ratio & 2.8362 & 2.5112 & 3.9200 \\
\hline
\end{tabular}

\begin{tabular}{lcc}
\hline & MOD 6 & MOD 7 \\
& & \\
Est. coeff. of BRANCH (1) & 0.3945 & 0.3621 \\
Est. coeff. of INTE (2) & 1.8356 & 1.9229 \\
& & \\
Var of (1) & $3.18 \mathrm{E}-02$ & $3.18 \mathrm{E}-02$ \\
Var of (2) & $3.18 \mathrm{E}-01$ & $3.15 \mathrm{E}-01$ \\
COV. (1) (2) & $-1.56 \mathrm{E}-02$ & $-1.54 \mathrm{E}-02$ \\
t-ratio & 3.9511 & 4.0661 \\
\hline
\end{tabular}

\begin{tabular}{lccc}
\hline & $\begin{array}{c}\text { MOD 3 } \\
\text { (clustered) }\end{array}$ & $\begin{array}{c}\text { MOD 4 } \\
\text { (clustered) }\end{array}$ & $\begin{array}{c}\text { MOD 5 } \\
\text { (clustered) }\end{array}$ \\
Est. coeff. of BRANCH (1) & 0.3417 & 0.3354 & 0.3941 \\
Est. coeff. of INTE (2) & 1.0238 & 1.0661 & 1.8152 \\
Var of (1) & $1.85 \mathrm{E}-02$ & $2.01 \mathrm{E}-02$ & $4.54 \mathrm{E}-02$ \\
Var of (2) & $2.24 \mathrm{E}-01$ & $3.41 \mathrm{E}-01$ & $3.68 \mathrm{E}-01$ \\
COV. (1) (2) & $-1.90 \mathrm{E}-02$ & $-9.27 \mathrm{E}-03$ & $-3.08 \mathrm{E}-02$ \\
& & & 3.7247 \\
t-ratio & 3.0202 & 2.3942 & \\
\hline
\end{tabular}

\begin{tabular}{lcc}
\hline & $\begin{array}{c}\text { MOD 6 } \\
\text { (clustered) }\end{array}$ & $\begin{array}{c}\text { MOD 7 } \\
\text { (clustered) }\end{array}$ \\
Est. coeff. of BRANCH (1) & 0.3945 & 0.3621 \\
Est. coeff. of INTE (2) & 1.8356 & 1.9229 \\
Var of (1) & $4.54 \mathrm{E}-02$ & $4.63 \mathrm{E}-02$ \\
Var of (2) & $3.67 \mathrm{E}-01$ & $3.59 \mathrm{E}-01$ \\
COV. (1) (2) & $-3.05 \mathrm{E}-02$ & $-3.22 \mathrm{E}-02$ \\
t-ratio & 3.7636 & 3.9159 \\
\hline
\end{tabular}

For the description of the variables see table 2. For the computation of the tests statistics see expression (3) in the main body of the paper. 
APPENDIX - Correlation matrix

\begin{tabular}{|c|c|c|c|c|c|c|c|c|c|c|c|c|c|c|c|c|c|}
\hline & EMPLOY & SIZE1 & SIZE2 & AGE & CASHFLOW & INV & BANKDEBT & BRANCH & $\mathrm{COOP}$ & GRU & PAV1 & PAV2 & PAV3 & PAV4 & POP & $\mathrm{RPI}$ & CEN-NORTH \\
\hline EMPLOY & 1 & & & & & & & & & & & & & & & & \\
\hline SIZE1 & 0.6913 & 1 & & & & & & & & & & & & & & & \\
\hline SIZE2 & 0.6812 & 0.9427 & 1 & & & & & & & & & & & & & & \\
\hline AGE & 0.1856 & 0.2269 & 0.2606 & 1 & & & & & & & & & & & & & \\
\hline CASHFLOW & 0.0160 & -0.1439 & -0.2076 & 0.0634 & 1 & & & & & & & & & & & & \\
\hline INV & -0.0191 & -0.0867 & -0.1104 & -0.0438 & 0.1928 & 1 & & & & & & & & & & & \\
\hline BANKDEBT & 0.0855 & 0.2941 & 0.3252 & 0.0739 & -0.3714 & -0.0927 & 1 & & & & & & & & & & \\
\hline BRANCH & 0.0358 & 0.0716 & 0.0288 & 0.0486 & 0.0567 & -0.0448 & 0.0392 & 1 & & & & & & & & & \\
\hline COOP & 0.0096 & 0.0189 & 0.0504 & 0.1315 & -0.1184 & 0.0177 & 0.0231 & -0.0126 & 1 & & & & & & & & \\
\hline GRU & 0.4025 & 0.4603 & 0.4714 & 0.0423 & -0.0301 & -0.0526 & 0.0756 & 0.0428 & -0.0674 & 1 & & & & & & & \\
\hline PAV1 & -0.0617 & -0.0543 & -0.0534 & 0.0159 & -0.1261 & -0.0002 & 0.1005 & -0.0635 & 0.1210 & -0.1172 & 1 & & & & & & \\
\hline PAV2 & 0.0103 & 0.0207 & 0.0216 & 0.0182 & 0.0443 & 0.0524 & -0.0194 & -0.0381 & -0.0224 & 0.0289 & -0.4740 & 1 & & & & & \\
\hline PAV3 & 0.0326 & 0.0386 & 0.0310 & -0.0313 & 0.0751 & -0.0351 & -0.0751 & 0.1269 & -0.0964 & 0.0698 & -0.6055 & -0.2822 & 1 & & & & \\
\hline PAV4 & 0.0575 & 0.0099 & 0.0216 & -0.0052 & 0.0591 & -0.0212 & -0.0444 & -0.0440 & -0.0429 & 0.0768 & -0.2309 & -0.1076 & -0.1375 & 1 & & & \\
\hline POP & 0.0374 & 0.0333 & 0.0418 & 0.0926 & 0.0562 & 0.0049 & -0.0693 & -0.2204 & -0.0760 & 0.0477 & -0.1757 & 0.0646 & 0.0887 & 0.1098 & 1 & & \\
\hline RPI & 0.0719 & 0.0955 & 0.0641 & 0.1351 & 0.1004 & -0.0635 & -0.0391 & 0.5622 & -0.0775 & 0.0763 & -0.1711 & -0.0093 & 0.1683 & 0.0682 & 0.4361 & 1 & \\
\hline CEN-NORTH & 0.0516 & 0.0621 & -0.0067 & 0.0868 & 0.0971 & -0.0218 & -0.0025 & 0.6535 & -0.0818 & 0.0006 & -0.1173 & -0.0093 & 0.1376 & 0.0070 & 0.0113 & 0.6559 & 1 \\
\hline
\end{tabular}

For the description of the variables see table 2. 